\title{
Current Evidence on the Protective Effects of Recombinant Human Erythropoietin and Its Molecular Variants against Pathological Hallmarks of Alzheimer's Disease
}

\author{
José J. Jarero-Basulto ${ }^{1, *}$, Martha C. Rivera-Cervantes ${ }^{1, *(\mathbb{D})}$, Deisy Gasca-Martínez ${ }^{2}$, \\ Francisco García-Sierra ${ }^{3}$, Yadira Gasca-Martínez ${ }^{4}$ and Carlos Beas-Zárate ${ }^{4}$ \\ 1 Cellular Neurobiology Laboratory, Cell and Molecular Biology Department, CUCBA, \\ University of Guadalajara, Zapopan 45220, Mexico \\ 2 Behavioral Analysis Unit, Neurobiology Institute, Campus UNAM-Juriquilla, Querétaro 76230, Mexico; \\ gasca@inb.unam.mx \\ 3 Department of Cell Biology, Center of Research and Advanced Studies of the National Polytechnic \\ Institute (CINVESTAV), Ciudad de Mexico 07360, Mexico; fgarcia-sierra@cell.cinvestav.mx \\ 4 Development and Neural Regeneration Laboratory, Cell and Molecular Biology Department, CUCBA, \\ University of Guadalajara, Zapopan 45220, Mexico; gasca.mx@hotmail.com (Y.G.-M.); \\ carlos.beas@academicos.udg.mx (C.B.-Z.) \\ * Correspondence: jose.jarero@academicos.udg.mx (J.J.J.-B.); mrivera@academicos.udg.mx (M.C.R.-C.); \\ Tel.: +52-33-37771150 ((J.J.J.-B. \& M.C.R.-C.)
}

Received: 11 September 2020; Accepted: 10 November 2020; Published: 26 November 2020

\begin{abstract}
Substantial evidence in the literature demonstrates the pleiotropic effects of the administration of recombinant human erythropoietin (rhEPO) and its molecular variants in different tissues and organs, including the brain. Some of these reports suggest that the chemical properties of this molecule by itself or in combination with other agents (e.g., growth factors) could provide the necessary pharmacological characteristics to be considered a potential protective agent in neurological disorders such as Alzheimer's disease (AD). AD is a degenerative disorder of the brain, characterized by an aberrant accumulation of amyloid $\beta(A \beta)$ and hyperphosphorylated tau (tau-p) proteins in the extracellular and intracellular space, respectively, leading to inflammation, oxidative stress, excitotoxicity, and other neuronal alterations that compromise cell viability, causing neurodegeneration in the hippocampus and the cerebral cortex. Unfortunately, to date, it lacks an effective therapeutic strategy for its treatment. Therefore, in this review, we analyze the evidence regarding the effects of exogenous EPOs (rhEPO and its molecular variants) in several in vivo and in vitro $A \beta$ and tau-p models of AD-type neurodegeneration, to be considered as an alternative protective treatment to this condition. Particularly, we focus on analyzing the differential effect of molecular variants of rhEPO when changes in doses, route of administration, duration of treatment or application times, are evaluated for the improved cellular alterations generated in this disease. This narrative review shows the evidence of the effectiveness of the exogenous EPOs as potential therapeutic molecules, focused on the mechanisms that establish cellular damage and clinical manifestation in the AD.
\end{abstract}

Keywords: Alzheimer's disease; erythropoietin; protective effects; neuroinflammation; apoptosis; oxidative stress; excitotoxicity

\section{Introduction}

Alzheimer's disease (AD) is a neurodegenerative disorder and the most common form of dementia in elderly people [1]. Clinically, AD is characterized by progressive mental decline and 
cognitive dysfunction, which have been associated with neuronal degeneration and excessive glial activation in brain areas that are mainly related to learning and memory, such as the hippocampus and neocortex [2-4]. The typical pathological hallmarks in patients with $\mathrm{AD}$ are abnormal deposition of amyloid- $\beta(\mathrm{A} \beta)$ plaques and accumulation of hyperphosphorylated tau (tau-p) protein in neurofibrillary tangles (NFTs) [5] (Figure 1). A $\beta$ is generated from amyloid precursor protein (APP) by sequential proteolytic cleavage from both beta and gamma secretases [6]. The A $\beta$ peptides form aggregates mainly in the extracellular space, but also within neurons and glial cells [7]. On the other hand, the tau hyperphosphorylation can occur due to an imbalance between kinase and phosphatase activities. The abnormal hyperphosphorylated state interferes with tau function, contributing to the disruption of intracellular transport and loss of synaptic contacts [8]. This tau-p state promotes its self-aggregation into fibrillary structures and increases cell toxicity due to its uncontrolled accumulation into the neuronal body [9-11]. In the $\mathrm{AD}$, despite its uncertain origin, long process of evolution and the complexity of its study, it is known that $\mathrm{A} \beta$ and tau-p abnormal accumulation in the brain promotes different responses such as inflammatory, oxidative and excitotoxic that involve the activation of different signaling pathways that lead to neurodegeneration by aberrant apoptotic death. It is currently unknown whether abnormal protein aggregates in AD brains are the cause of the disease or a secondary phenomenon; unfortunately, this disease is a growing public health problem that lacks an effective therapeutic strategy for its treatment. To this day, there are only pharmacological drugs aiming to reduce the symptoms. However, research groups around the world are focusing their efforts on finding suitable methods for the prevention, early detection and possible cure for this disease. In the past few decades, researchers have redirected their attention towards erythropoietin (EPO), an endogenous molecule with a pleiotropic role, although not fully understood, in neurodegenerative diseases.
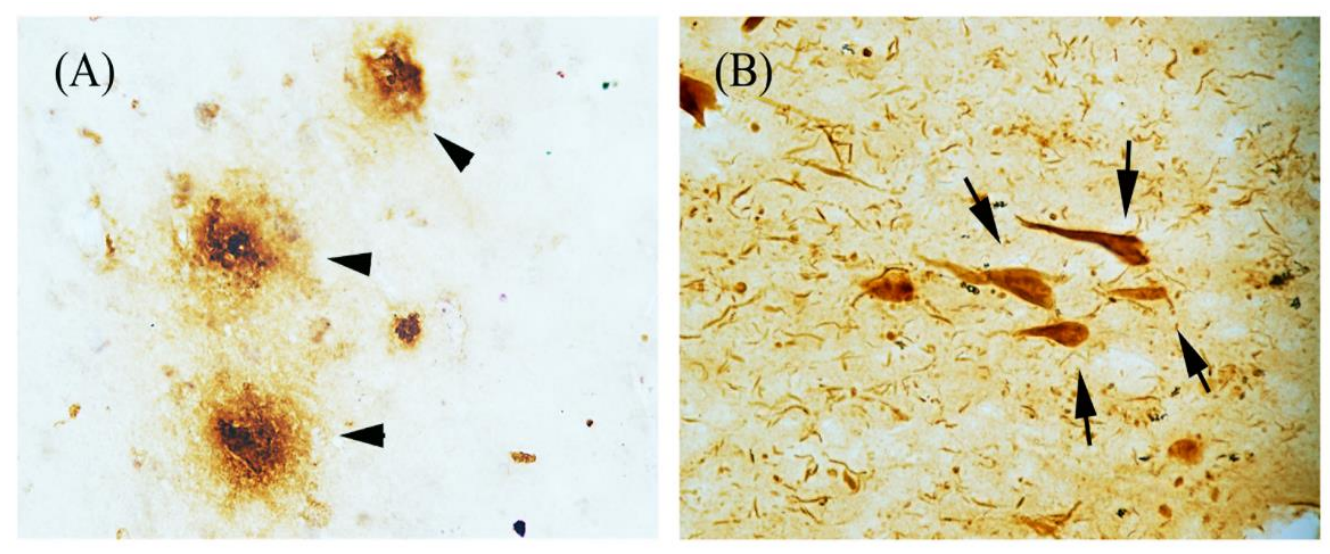

Figure 1. Characteristic hallmarks of Alzheimer's disease (AD) brains. Bright-field immunohistochemistry microscopic images from hippocampus of an AD patient: (A) Amyloid beta plaques (arrowhead) and (B) Neurofibrillary tangles (arrows), formed by abnormal accumulations of $A \beta$ and tau-p protein, as recognized by specific antibodies, respectively.

EPO is a small protein $(30 \mathrm{kDa})$ [12] that is widely recognized as a hematopoietic factor, although it has been described as having other effects on the brain and other organs [13-15]. In the brain, the production of EPO and its receptor (EPOR) occurs in endothelial cells, astrocytes and neurons [15-21]. EPO is involved in neuroprotection, neurogenesis and regeneration, and acts as a messenger in autocrine or paracrine signaling [14,22]. Particularly, EPO gene expression can be regulated by hypoxia-inducible factor-1 (HIF-1) [20,23-25], which in turn is activated by multiple stressors [26,27]. In humans, under damage conditions in different neurological disorders, the EPO/EPOR system is upregulated in the brain tissue, and only in some cases in cerebrospinal fluid (CSF), as compared to healthy cases [15,28-34]. This system is considered an endogenous protective response to injury $[30,31]$ that presumably acts in conjunction with vascular endothelial growth factor (VEGF) and other trophic factors [35-37]. Moreover, due to the ongoing cell degeneration, EPO/EPOR system upregulation 
in the brain has been suggested to be a normal response to aging, but not sufficient to prevent neurodegenerative disorders such as $\operatorname{AD}[13,18,28,32]$. Interestingly, the works reviewed here provided evidence that the cellular protective effect of rhEPO and its molecular variants increase the cell viability in vitro models, which could occur through the decrease in load protein aggregates in vivo models as well as clinical trials, and their effects against pathological hallmarks are mediated by both $\mathrm{A} \beta$ and tau-p proteins, although the molecular mechanisms or signaling pathways involved are unclear yet. Regarding this, we think that the application of rhEPO or any of its molecular variants could strengthen the intrinsic EPO-mediated protection system, so the signaling mechanism involved, as well as doses, routes of administration, duration of treatments and application times, among others, which can influence and thus explain the variability in the reported results, are then important goals to investigate.

\section{Search Method and Criteria for Literature Inclusion}

Medline via PubMed database (http://pubmed.ncbi.nlm.nih.gov) was searched to identify articles published up to May 2020 about rhEPO and its molecular variants applied as treatment to Alzheimer's disease. The search keywords were "Erythropoietin treatment" or "EPO treatment" and "Alzheimer's disease" or "AD", as well as combination of these terms. Only research articles that reported the effects of rhEPO or any of its molecular variants in AD models (in vitro or in vivo), developed as a consequence of the exposition or expression of $A \beta$ or tau- $p$, were included in this review. No limitations were set on in vivo studies regarding species or age. On the basis of the inclusion criteria, a total of 32 studies were included in this narrative review.

\section{3. rhEPO and Molecular Variants}

Different research groups have increased their interest in studying the effect of rhEPO administration as a treatment for neurological diseases such as AD [38-40]. Evidence from different reports indicates that rhEPO can cross the intact blood-brain barrier (BBB) [16,22] and preserve its biological activity [41,42]. Through rhEPO interaction with homodimeric, heterodimeric or heterotrimeric EPORs (Figure 2) [43-45], rhEPO administration can induce neurotrophic effects, thereby promoting differentiation, cellular protection and regeneration [14] against brain injuries and degeneration [13,19,22,46-48], although the mechanism used is still unclear.

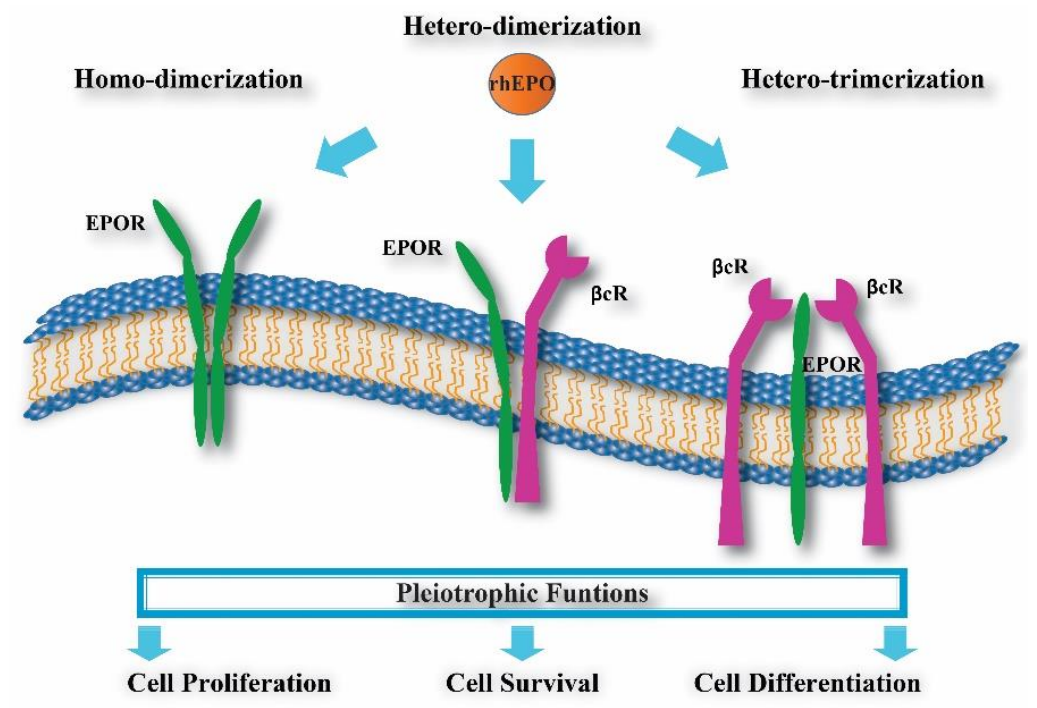

Figure 2. EPO receptors. The rhEPO has been proposed to interact with three possible receptor complexes in initiating its pleiotrophic effects: two units of EPOR = homodimer (green structure), one EPOR and one $\beta c R$ units = heterodimer (green and purple structure) or one EPOR plus two $\beta c R$ units $=$ heterotrimer (green and purple structures). 
Even so, both in vitro (cell culture) and in vivo (animal models) experimental studies strongly support the protective role of rhEPO [47,49,50] (Figure 3), although, to date, there is little evidence for AD patients or other neurological diseases. However, something that has to be considered is that chronic application of rhEPO has multiple adverse side effects. To reduce or prevent these effects, chemical changes in the rhEPO molecule have been assessed, and new variants with different experimental results have emerged.

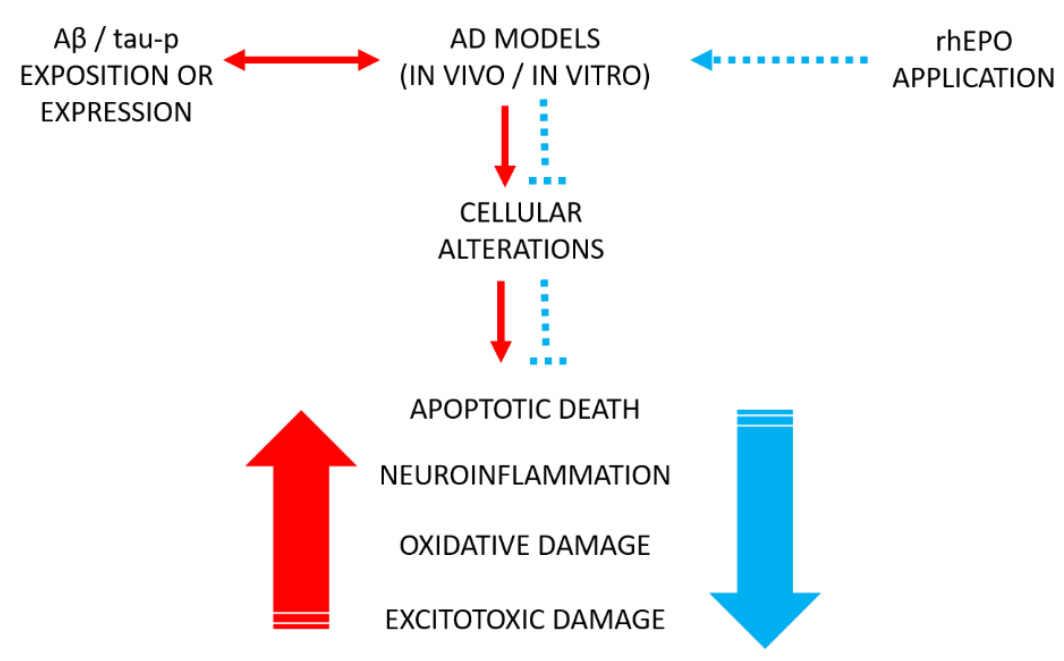

Figure 3. rhEPO effects on cell damage in AD models. The rhEPO application as a pharmacological treatment (blue dotted arrow) diminishes cellular alterations (blue dotted lines) generated in response to exposition or expression to $\mathrm{A} \beta$ or tau-p proteins in vitro and in vivo AD models (double-head red arrow). Red big arrow refer to increased cellular alterations, while blue big arrow refer to damage inhibition.

Molecular variants of rhEPO include asialoerythropoietin (Asialo-EPO), a deglycosylated form of rhEPO, which, in experimental studies, has shown an effect on neuroprotection and few changes in hematocrit due to its short half-life [49,51,52]. Carbamylated EPO (CEPO) is a conformationally modified variant of rhEPO that replaces lysines with homocitrullines, which is nonerythropoietic, but maintains the tissue-protective effect; interestingly, it is not recognized through EPOR classical interaction $[44,53,54]$. EPOL is a variant of the rhEPO molecule, which has a different glycosylation pattern (low sialylated bi-antennary structures) and no hematopoietic activity, but has a protective activity against oxidative stress $[55,56]$. Neuro-EPO is another variant with low sialic acid content and a short half-life. This variant has no hematopoietic effects, but exhibits neuroprotective effects when administered intranasally (i.n.) $[40,57,58]$. On the other hand, an rhEPO analogue called cTfRMAb-EPO, obtained by fusing EPO with a rat/mouse chimeric monoclonal antibody targeting the transferrin receptor (TfR1), acts as an efficient neuroprotective agent with minimum effects on the hematocrit (compared with rhEPO) when administered intraperitoneally (i.p.). TfR1 is expressed in the brain capillary endothelium and functions as a receptor-mediated transcytosis system. Thus, its ligands can be used for non-invasive delivery of drugs to the brain via the transvascular route. TfR 1 can be recognized by the monoclonal antibody against TfR1, which binds to a different site than that of transferrin, and is an alternative drug delivery vector. This action crosses the BBB and leads to widespread drug delivery throughout the brain owing to the dense network of the cerebral vasculature. Interestingly, the cTfRMAb-EPO fusion protein also binds to EPOR with high affinity [59]. All of these rhEPO variants have been demonstrated to have different degrees of effectiveness when are administered in the AD experimental models (Table 1). The effects seem to depend on several things, such as the doses, route of administration, application times and duration of treatments, but are also related to the kind of receptor and its recognition. 
Table 1. Molecular variants of rhEPO. Asialoerythropoietin (Asialo-EPO); Carbamylated EPO (CEPO); EPOL; Neuro-EPO and an EPO analogue called cTfRMAb-EPO. All them have low or no hematocrit effects but have protective effects preserved. As reference of chronic treatment, rhEPO was included.

\begin{tabular}{llcccc}
\hline Epo Molecule & Molecular Modification & $\begin{array}{c}\text { Hematocrit } \\
\text { Effects }\end{array}$ & $\begin{array}{c}\text { Protective } \\
\text { Effects }\end{array}$ & References \\
\hline rhEPO & None & High & Yes & {$[13,22]$} \\
\hline Asialo-EPO & Deglycosylated form of EPO & Low & Yes & {$[51,52]$} \\
\hline CEPO & Conformational modification (replaces lysines with homocitrulines) & Low & Yes & {$[54]$} \\
\hline EPOL & Different glycosylation pattern (low sialylated bi-antennary structures) & None & Yes & {$[55,56]$} \\
\hline Neuro-EPO & Low sialic acid content & None & Yes & {$[40,57]$} \\
\hline cTfRMAb-EPO & Fusion of chimeric antibody with EPO & Low & Yes & {$[59]$} \\
\hline
\end{tabular}

\section{Effects of rhEPO and Some Its Molecular Variants in Experimental Models of Alzheimer's Disease}

In $\mathrm{AD}$, an uncontrolled increase in neurodegeneration that affects the brain regions involved in memory and learning has been reported, with the hippocampal cells the most vulnerable to damage [9,42,60-62]. The cell damage has been mainly associated with the abnormal presence or accumulation of $A \beta$ species directly related to apoptosis by promoting the exposure of phosphatidyl-serine to the outer membrane, caspase activation and glial overactivation $[15,63,64]$, as well as with the formation of a pore in the cell membrane, which allows the massive entry of cations (e.g., $\mathrm{Ca}^{2+}$ ), altering ion homeostasis and energy balance. These changes generate the mis-sorting of tau-protein in the cell body, cell dysfunction and apoptosis, as demonstrated by experimental evidence [65-69], characteristics that have been related to the early alterations in cognitive function [70].

Therefore, through to use of diverse AD-models both in vitro and in vivo, the effects of molecules with pleiotropic activity such as rhEPO and its molecular variants have been evaluated as a therapeutic agent for this disease. One of the most studied effects of the EPO molecule is neuroprotection through anti-apoptotic mechanisms [40,45,63,71-77], regulated by different signaling pathways such as JAK/STAT [78], among others (Figure 4) [49,55,56,79-81]. In addition, the inhibition of inflammation, oxidative stress and excitotoxicity appear to be associated with the activity of EPO/EPOR in the central nervous system (CNS).

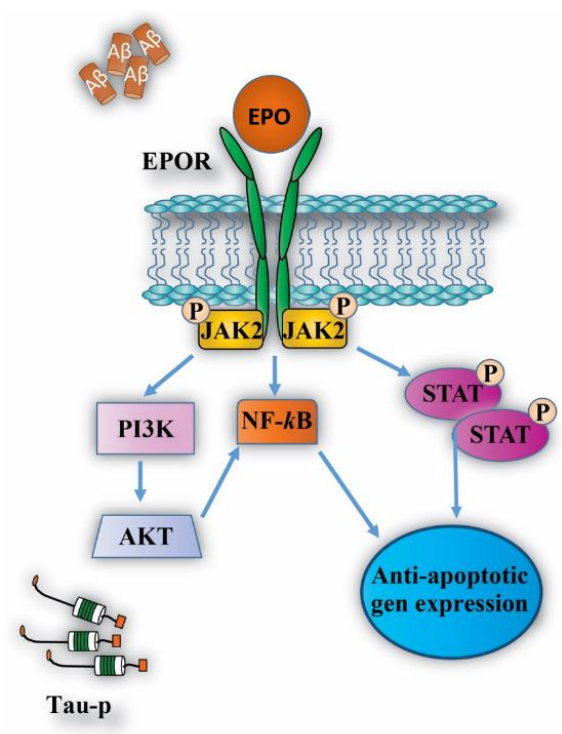

Figure 4. Intracellular signaling pathways activated by EPO/EPOR system. EPO molecule activates different intracellular pathways through EPOR, leading to anti-apoptotic gene expression as well as the inhibition of pro-apoptosis genes. These actions allow for cell proliferation, differentiation and cell survival against the pathological stimulus generated by $\mathrm{A} \beta$ and tau-p protein in AD. 


\subsection{Neuroprotective Effects}

According to the evidence in vitro, using PC12 and SH-SY5Y cell lines as well as primary cultures of hippocampal neurons, the exposure to $A \beta$ peptides or fragments like $A \beta 25-35$ (short toxic variant), induces degenerative changes such as oxidative stress and high levels of tau-p and apoptosis $[82,83]$, while a dose-dependent decrease in both apoptotic cell death and other alterations was reported when cell cultures were pre-treated or co-incubated with rhEPO [56,63,79,84-86].

$\mathrm{Li}$ et al. [63] reported in PC12 cell culture that pre-treatment with different concentrations of rhEPO (0.5-10 IU/mL) one hour before exposure to A $\beta 25-35$ peptide reduces the number of apoptotic cells through an increase in Bcl-2 expression and decrease in both Bax expression and caspase-3 activity. This result supports other studies where the anti-apoptotic effects of rhEPO are presumably due to the increased expression of apoptosis inhibiting genes such as Bcl-2, Bcl-xL, XIAP and c-IAP2 [85,87]. Furthermore, in a comparative study, the protective effects of rhEPO and EPOL were tested in PC12 cell cultures. Cell cultures subjected to chronic exposure to A $\beta 40$ were incubated with rhEPO or EPOL at different concentrations (10,50 and $100 \mathrm{ng} / \mathrm{mL}$ ). Primary cultures exposed to A $\beta 40$ as well as organotypic cultures exposed to A $\beta 25-35$ (both from rat hippocampus) incubated with rhEPO or EPOL in a unique concentration $(100 \mathrm{ng} / \mathrm{mL})$, respectively, were also alternately used. The results showed lower levels of cell death, detected by MTT or propidium iodide fluorescence assays, in EPOs-treated cultures; although EPOL treatment (50 or $100 \mathrm{ng} / \mathrm{mL}$ doses) was effective in all culture experiments, $\mathrm{rhEPO}(100 \mathrm{ng} / \mathrm{mL}$ dose) failed to provide protection in organotypic cultures $[56,86]$.

Experimental evidence in SH-SY5Y cell cultures demonstrates that exposure to A $\beta 25-35$ increases the level of tau-p protein, which is attributed to the over-activation of glycogen synthase kinase- $3 \beta$ (GSK-3 $\beta$ ), which diminished when the cultures were pretreated for one hour with different doses of rhEPO $(5,10$ or $20 \mathrm{IU} / \mathrm{g})$, and thereby significantly reduced the percentage of cell death $[84,88]$. Different authors suggest that the cellular protective effect of rhEPO, mediated by suppressing tau phosphorylation, occurs via PI3K/AKT-GSK-3 $\beta$ signaling [48,84,88-91]. In addition, reports in primary neuronal cultures from rats suggest that both the induction and redistribution of tau-p as well as its accumulation in the somatodendritic compartment, caused by $\mathrm{A} \beta$ oligomers and inhibition of protein degradation, increases cytotoxicity [67,92]. Interestingly, in some in vitro assays, the protective effect of rhEPO under $A \beta$ damage has also been associated with its amino acid composition, as the EPO molecule has a hydrophobic core, which can interact with $A \beta$ in the $C$-terminal region, important for $\mathrm{A} \beta / \mathrm{A} \beta$ peptide interaction, and insertion into the cell lipid membrane [56]. This action is similar to that proposed for neuroprotective agents, which prevented $A \beta$ aggregation [93]. Currently, there is more experimental evidence in vitro on the inhibition of the A $\beta$ effect by rhEPO (Table 2), so we emphasized that more attention should be given to the participation of the tau-p aggregates and evaluating the protective role of rhEPO against the cellular effects generated by them.

Table 2. In vitro AD models.

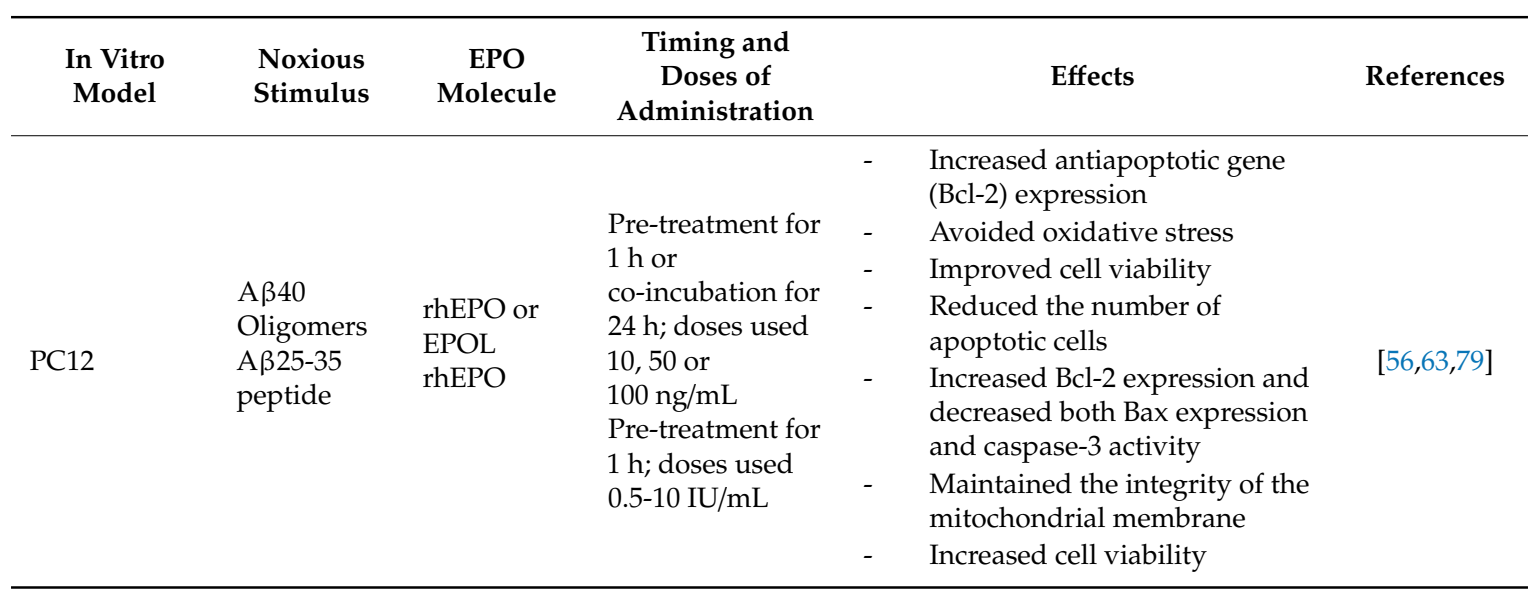


Table 2. Cont.

\begin{tabular}{|c|c|c|c|c|c|}
\hline $\begin{array}{c}\text { In Vitro } \\
\text { Model }\end{array}$ & $\begin{array}{l}\text { Noxious } \\
\text { Stimulus }\end{array}$ & $\begin{array}{c}\text { EPO } \\
\text { Molecule }\end{array}$ & $\begin{array}{c}\text { Timing and } \\
\text { Doses of } \\
\text { Administration }\end{array}$ & Effects & References \\
\hline SH-SY5Y & $\begin{array}{l}\text { A } \beta 25-35 \\
\text { Tau-p }\end{array}$ & rhEPO & $\begin{array}{l}\text { Pre-treatment for } \\
1 \mathrm{~h} \text {; used doses } 5 \text {, } \\
10 \text { or } 20 \mathrm{IU} / \mathrm{g}\end{array}$ & $\begin{array}{ll}\text { - } & \text { Reduced the percentage of } \\
\text { cell death } \\
\text { - }\end{array}$ & {$[84,88]$} \\
\hline $\begin{array}{l}\text { Primary } \\
\text { culture of } \\
\text { hippocampal } \\
\text { neurons }\end{array}$ & $\begin{array}{l}\text { A } \beta 40 \\
\text { oligomers } \\
\text { Tau-p }\end{array}$ & $\begin{array}{l}\text { rhEPO or } \\
\text { EPOL }\end{array}$ & $\begin{array}{l}\text { Co-incubation for } \\
24 \mathrm{~h} \text {; dose used } \\
100 \mathrm{ng} / \mathrm{mL}\end{array}$ & 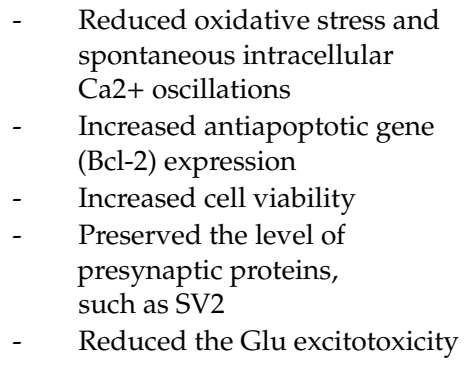 & {$[55,56,94]$} \\
\hline $\begin{array}{l}\text { Organotypic } \\
\text { rat } \\
\text { hippocampus } \\
\text { culture }\end{array}$ & Aß25-35 & $\begin{array}{l}\text { rhEPO or } \\
\text { EPOL }\end{array}$ & $\begin{array}{l}\text { Co-incubation for } \\
4 \text { days; dose used } \\
100 \mathrm{ng} / \mathrm{mL}\end{array}$ & $\begin{array}{ll}- & \text { Reduced ROS levels } \\
- & \text { Reduced glial activation } \\
- & \text { Increased antiapoptotic gene } \\
\text { (Bcl-2) expression } \\
\text { - } & \text { Increased cell viability with } \\
& \text { EPOL but no with rhEPO }\end{array}$ & [56] \\
\hline
\end{tabular}

Concomitantly, in vivo models of $\mathrm{AD}$ have been used to characterize the neuroprotective effects of rhEPO and its molecular variants, as well as to determine the optimum dose, route of administration, treatment duration and application times, and adverse side effects. Intracerebroventricular (ICV) injection of a diabetogenic substance called streptozotocin (STZ) in rodents is used to generate a valid model of sporadic AD. STZ in experimental subjects causes long-term and progressive deficits in learning, memory, and behavior [95-97] as a consequence of neuronal loss associated with metabolic alterations, since cerebral energy deficit mainly occurs in the hippocampus and dentate gyrus (DG) $[41,98,99]$. The i.p. administration of rhEPO (5000 IU/kg), every other day for 2 weeks in the ICV-STZ model, induced neurogenesis in DG and protected brain cells from STZ-induced damage, thereby improving memory deficits without presenting significant erythropoietic alterations $[41,97]$.

Importantly, similar effects were obtained in a comparative study between the administration of rhEPO and Neuro-EPO in an AD model generated by ICV injection of A $\beta 25-35$ in non-transgenic mice (ICV-A $\beta 25-35$ model) [40,100]. Neuropathological hallmarks, such as reactive gliosis, caspase over-activation, oxidative stress, neuronal loss and memory deficits, were reported in this AD mouse model. The administration of each of the evaluated EPO molecules at different doses, prevented neuronal loss in the hippocampal CA1 region, and reduced the number of brain amyloid plaques, improving learning deficits $[40,101]$. In the same way, the protective effect of both molecules was evaluated in the transgenic mice model $\mathrm{Tg} 2576$ developed by Hsiao et al. [102], which overexpresses human APP (Swedish double mutation). This mouse at 12 months of age showed the first signs of $\mathrm{A} \beta$ deposits in plaques and, in parallel, developed behavioral deficits, particularly in spatial memory. In this study, the i.p. administration of $\mathrm{rhEPO}(5000 \mathrm{IU} / \mathrm{kg})$ for five days improved contextual memory and synaptophysin expression, and reduced endothelial dysfunction and the amount of $A \beta$ plaque in the brain [72], while Neuro-EPO treatment (125 or $250 \mathrm{IU} / \mathrm{kg}$, three times a week) for 2 months reduced apoptotic brain damage caused by $\mathrm{A} \beta$ accumulation, as well as neuroinflammation, synapse loss and declines in long-term potentiation [101]. In both studies, even at low doses, Neuro-EPO treatment had better protective effects than rhEPO [40,57,101], without hematopoietic effects [57,58]. Other reports have suggested that Neuro-EPO treatment may block both intrinsic and extrinsic apoptotic pathways 
by modulating the Bax/Bcl-2 ratio, reducing caspase- 3 activity in response to Akt activation in a PI3K-dependent manner, and decreasing the abnormally increased levels of TNF- $\alpha$ or FasL $[40,101]$. Furthermore, Rodriguez-Cruz et al. [101] reported a decrease, in the load of $A \beta$ species, of the 6E10 antibody (specific to A $\beta 1-16$ ) in the hippocampus and cortex after Neuro-EPO treatment.

Another comparative study between rhEPO and CEPO was realized in a double transgenic mouse model of AD (A $\beta$ PP/PS1) developed by Borchelt and his colleagues, that expresses the APP Swedish mutation and the mutant human presinilin 1 (PS1-dE9) [103]. This model presents an increase in A $\beta$ plaque in the brain, microglial over-activation, synapse loss and decreased spatial memory. The study showed that both rhEPO and CEPO treatments improved mice memory and health conditions without affecting erythropoiesis. However, only rhEPO decreased the amount of $\mathrm{A} \beta$ plaques and soluble $\mathrm{A} \beta$ species in the brain, unlike CEPO, suggesting that EPO molecules may have different effects on molecular substrates [104]. Finally, in the same A $\beta P P / P S 1$ transgenic mouse model, cTfRMAb-EPO $(3 \mathrm{mg} / \mathrm{kg}$ b.w, i.p.) was administered three days a week for eight weeks; this induced the reduction in the load of $A \beta$ plaque as well as microglial activation, improving synaptic activity and spatial memory [59].

Interestingly, data obtained from animal models for the AD show that exogenous $\mathrm{EPO}$ treatment reduces cognitive problems and improves behavior as a consequence of reduced neuronal damage and cell death caused by abnormal protein aggregates of $A \beta$ and tau-p, which also diminish $[63,84,105]$. In summary, the effectiveness of rhEPO and its molecular variants' administration in animal AD models depends on the route and time of administration, as well as the dose at which it is administered, points that have to be considered in the interpretation of results.

\subsection{Anti-Inflammatory Effects}

Neuroinflammation is an important component in the pathogenesis and progression of AD and other neurological diseases [41]. A $\beta$ plaques and NFTs, the major pathological hallmarks of AD, have been associated with neuroinflammatory reactions leading to negative physiological responses, such as massive glial activation, synaptic dysfunction, mitochondrial damage and apoptosis, which are all signs of degeneration $[2,3,40,101,106]$. According to reports in experimental models of brain diseases, rhEPO promotes a decrease in both glial response and pro-inflammatory cytokine levels in brain tissue, which are part of its anti-inflammatory effects [21,53,76,107-109].

In patients and animal models of $\mathrm{AD}$, over-activation of glial cells in the brain is a sign of neuroinflammation and cell damage $[106,110,111]$. Activated glial cells release large amounts of pro-inflammatory and neurotoxic cytokines, such as TNF- $\alpha$, IL- $1 \beta$, IL-6, IL- 8 and monocyte chemoattractant-1 (MCP-1) $[109,112,113]$ in addition to free radicals (e.g., reactive oxygen species (ROS) or nitric oxide (NO)), which directly increase apoptotic cell death [114]. TNF- $\alpha$ is a key cytokine that initiates the inflammatory cascade. In the healthy adult brain, it is synthetized at low levels by microglia and neurons $[110,115]$. However, high levels of TNF- $\alpha$ have been reported in the AD brain. Studies suggest that this alteration promotes $A \beta$ production through the over-activation of $\beta$-secretase and, in turn, increases tau-p levels due to GSK-3 $\beta$ activity. The accumulation of these altered proteins triggers chronic inflammation, neuronal death and, in consequence, cognitive dysfunction during the progression of AD [110,116-120].

Animal models have been used to study the relationship between TNF- $\alpha$ and both A $\beta$ and tau- $p$ in $\mathrm{AD}[110,121,122]$. For example, in a non-transgenic mouse model of AD generated by hippocampal injection of A $\beta 40$, the inhibition of TNF- $\alpha$ by treatment with adalimumab $(1 \mathrm{mg} / \mathrm{kg}$, i.p.), an anti-TNF- $\alpha$ drug, reduced the injuries triggered by the $A \beta$ peptide, contributing to the reestablishment of cognitive function in experimental subjects [110]. Another study suggested that adalimumab inhibits the inflammatory response because it binds to TNF- $\alpha$ and blocks its receptor binding [123]. Contrary to the inhibition of TNF- $\alpha$ as a protective effect, it has been also suggested that the microglial phagocytic activity of $A \beta$ peptides may be mediated by TNF- $\alpha$, and its inhibition could be responsible for the increase in $A \beta$ aggregates, as well as the increase in cognitive alterations $[124,125]$. The dual role of 
TNF- $\alpha$ has been correlated with differences in recognition by its receptor [126]. On the other hand, the increased levels of TNF- $\alpha$, IL-1 $\beta$, IL- 6 , IL- 8 and other cytokines, as well as decreased brain choline acetyltransferase (ChAT) activity in the ICV-STZ rat model, were reverted after a dose of rhEPO (5000 IU/kg a day; i.p.), demonstrating its anti-inflammatory role [41,97,99,117]. Maurice et al. [40] reported similar data in a comparative study between rhEPO (250 $\mu \mathrm{g} / \mathrm{kg}$; i.p.) and Neuro-EPO $(125 \mu \mathrm{g} / \mathrm{kg}$; i.n.) in the ICV-A $\beta 25-35$ AD mouse model. Both treatments significantly prevented the increased levels of TNF- $\alpha$ and IL- $\beta$ induced by the injection of A $\beta 25-35$ peptide. The anti-inflammatory effects of Neuro-EPO were also corroborated in a study with aged transgenic mice (Tg2576). The brain of these mice presents an intense inflammation and glial over-activation due to increased A $\beta$ deposits and plaques, which were decreased significantly after Neuro-EPO treatment (125 and $250 \mu \mathrm{g} / \mathrm{kg} ;$ i.n.) [101]. These results are in agreement with previous studies that used rhEPO and/or Neuro-EPO as an inhibitor of the immune response to damage, in different experimental animal models $[41,53,97,99,101,117,127]$.

In other reports, it has been suggested that rhEPO may also prevent microglial over-activation generated in response to $A \beta$ toxicity, through of the regulation of EPOR signaling by the Wnt1/PI3-K1/mTOR pathway, which leads to the inhibition of NF-kB p65, which prevents its nuclear translocation and allows the expression of an anti-apoptotic gene such as Bcl-xL, as well as suppressors of TNF- $\alpha$, IL- 6 and IL-1 $\beta[85,110,112,113,128]$, thereby directly altering the reactive state of the cell and exhibiting anti-inflammatory effects [129-131]. Interestingly, studies have been reported that EPOR expression is regulated by pro-inflammatory cytokines [115,132]. Studies suggest that upregulation of EPOR in glial cells under AD may facilitate the action of exogenous EPO molecules, thereby protecting neuronal cells from damage generated by $\mathrm{A} \beta$, pro-inflammatory cytokines and ROS $[15,133]$.

\subsection{Anti-Oxidant and Anti-Excitotoxic Effects}

Both oxidative and excitotoxic damage are common events in $\mathrm{AD}$, which leads to mitochondrial injury, genomic DNA alterations and other processes that generate cell death in susceptible brain regions such as the hippocampus [134-138]. The protective effects of rhEPO against different stressor molecules (e.g., A $\beta$ species and Glu) that promote oxidative stress and excitotoxicity have been proven in several experimental models [20,63,84,139,140]. For example, exposure of PC12 cell cultures to A $\beta 25-35$ peptides generated oxidative stress as result of increased ROS production, altering mitochondrial membrane phospholipids and causing apoptotic cell death. However, pre-incubation (one hour) at different concentrations of rhEPO (0.5-10 IU/mL) reduced these abnormal effects generated by A $\beta 25-35$ peptides, but had the maximum protective effects achieved with $2 \mathrm{IU} / \mathrm{mL}$ [63]. In the same cell model, in a comparative study between rhEPO and EPOL, Castillo et al. [56] reported that oxidative stress induced by chronic exposure to A $\beta 40$ was avoided with pre-treatment of rhEPO (100 ng/kg) or EPOL $(50 \mathrm{ng} / \mathrm{kg})$. This effect is associated with an increase in the expression of the anti-apoptotic gene Bcl-2 $[55,56]$. In the same study, but in rat hippocampal organotypic cultures treated with $A \beta 25-35$, the increase in ROS levels observed in the CA1 brain region, were reestablished to nearly normal levels when the cells were co-incubated with rhEPO or EPOL. In this case, better results were obtained with EPOL even at low concentrations [56]. These results are consistent with other studies using primary hippocampal and cerebral cortex cultures from rats. In these studies, Glu-induced neuronal death or hypoxia decreased dramatically with rhEPO pre-treatment in a dose-dependent manner [19].

On the other hand, in the ICV-STZ rat model, the administration of rhEPO (5000 IU/kg; i.p.) decreased the oxidative damage (increased inflammatory cytokines and mitochondrial dysfunction) generated by STZ injection [41]. Similar observations were reported in an ICV-STZ mouse model treated with rhEPO (500 and $1000 \mathrm{IU} / \mathrm{kg}$; i.p.), improving memory deficits and oxidative stress in the brain [141]. Maurice et al. [40], in hippocampal extracts from ICV-A $\beta 25-35$ mice, reported an increase in the levels of membrane lipid peroxidation. The authors showed that the administration of rhEPO (250 $\mu \mathrm{g} / \mathrm{mL}$; i.p.) and Neuro-EPO $(125 \mu \mathrm{g} / \mathrm{mL}$; i.n.) significantly reduced the oxidative effects, even though Neuro-EPO used lower doses [40]. Finally, these results were also corroborated using aged Tg2576 mice treated with Neuro-EPO $(125 \mu \mathrm{g} / \mathrm{mL}$; i.n.). According to the study, abnormally 
increased levels of membrane lipid peroxidation in hippocampal cells, in response to $A \beta$-induced oxidative stress, were significantly reduced [101]. In both experimental cases, the survival rate of the mice increased, as well as their learning ability [40,101].

Although the antioxidant mechanism of EPO in AD brains is still unknown, research groups have suggested that it promotes NF-kB p65 nuclear translocation and prevents Akt phosphorylation generated in response to damage induced by $\mathrm{A} \beta$ accumulation. These actions could help stabilize the mitochondrial membrane potential (Bcl-2/Bax ratio) and attenuate ROS production $[57,63,85,94,142]$. In addition, experimental evidence points to the possibility of an increased activation of antioxidant enzymes such as catalase, superoxide dismutase, or glutathione peroxidase, with rhEPO treatments [38,143-146], or that EPO could act directly as an ROS scavenger [147,148]. Interestingly, the antioxidant effect of exogenous EPO molecules apparently does not alter the intracellular redox condition [94].

Along with oxidative stress, excitotoxicity has been considered as a cause or consequence of neuronal damage in many neurodegenerative disorders [149-152]. Usually, excitotoxicity is described as the abnormal extracellular Glu accumulation, which over-activates its own receptors' (GluR) promoted event activation, such as oxidative stress and mitochondrial dysfunction, that are conducive to cell death [153-155]. It is well known that cell injury causes an increase in intracellular $\mathrm{Ca}^{2+}$ levels, which, in turn, promotes a greater release of Glu from the vesicles. Like a vicious circle, Glu excitotoxicity may induce an increase in intracellular free radicals and $\mathrm{Ca}^{2+}$, thereby activating both pro- and anti-apoptotic responses in cells; depending on the duration and severity of the injury, the cell either survives or dies [156]. In a study in which cultured cortical neurons and astroglial cells were exposed to hypoxia accompanied by glucose deprivation damage, rhEPO treatment $(30 \mathrm{pM})$ showed protective effects on neuronal cells, but not on astroglial cells [157]; these data are consistent with previous findings [158]. Although the astrocyte collects extracellular Glu released by neurotransmission through specific transports to prevent excitotoxicity, Glu-transports have been reported to decrease in the AD brain. This decrease has been associated with abnormal APP expression [159,160].

It has been postulated that the increase in both Glu and $A \beta$ in the $A D$ reduces the anti-apoptotic $\mathrm{Bcl}-2$ and increases the expression of pro-apoptotic Bax protein. This action releases cytochrome $\mathrm{C}$ protein into the cytosol and increases intracellular $\mathrm{Ca}^{2+}$ levels. Consequently, intrinsic apoptotic signaling is activated [161,162]. According to the published data in PC12 cell cultures exposed to A $\beta$ species and rhEPO $(2 \mathrm{IU} / \mathrm{mL})$ treatment, mitochondrial membrane integrity was maintained to increase $\mathrm{Bcl}-2$ and reduce Bax expressions, thereby maintaining the Bcl-2/Bax ratio [63]. Garzon et al. [94] in primary neuronal cultures exposed to Glu excitotoxicity and Neuro-EPO $(100 \mathrm{ng} / \mathrm{mL})$ reported that morphological changes (cell body shrinkage, formation of blebs on the cell surface, pyknotic nucleus and loss of dendritic process) and apoptotic cell death were reduced with Neuro-EPO treatment, even $15 \mathrm{~min}$ after exposure to Glu [94]. Castillo et al. [56], using primary hippocampal neuronal cultures exposed to A $\beta 40$ and co-incubated with EPOL $(100 \mathrm{ng} / \mathrm{mL})$, reported that the treatment could preserve the level of presynaptic proteins, such as synaptic vesicle protein 2 (SV2), which are related to neurotransmitter release and can be altered by abnormal $\mathrm{Ca}^{2+}$ levels resulting from $\mathrm{A} \beta$ toxicity. All of these data suggest that rhEPO or its molecular variants play a protective role by regulating the release of neurotransmitters; however, further studies are needed to elucidate the mechanism by which this regulation occurs. In summary, from the analysis of these studies (in vivo) to date (Table 3), Neuro-EPO administered via i.n. has proven to be the most effective in the treatment or prevention of AD pathophysiology. 
Table 3. In vivo AD models. ICV-STZ; ICV-A $\beta 25-35$ = Intracerebroventricular injection models; Tg2576*; $\mathrm{A} \beta \mathrm{PP} / \mathrm{PS} 1^{*}=$ Transgenic models. rhEPO; EPOL; CEPO; Neuro-EPO and cTfRMAb-EPO = Molecular variants of EPO. i.p.- -intraperitoneal; i.n.-intranasal = Administration route.

\begin{tabular}{|c|c|c|c|c|c|}
\hline $\begin{array}{l}\text { In Vivo } \\
\text { Model }\end{array}$ & $\begin{array}{l}\text { Noxious } \\
\text { Stimulus }\end{array}$ & EPO Molecule & $\begin{array}{l}\text { Doses and Route } \\
\text { of Administration }\end{array}$ & Effects & References \\
\hline ICV-STZ (rat) & Injection of STZ & rhEPO & $\begin{array}{l}\text { Dose used } \\
5000 \mathrm{IU} / \mathrm{kg} \text {, every } \\
\text { other day for } \\
2 \text { weeks; i.p }\end{array}$ & $\begin{array}{ll}- & \text { Prevented apoptosis } \\
- & \text { Induced neurogenesis } \\
- & \text { Improved memory deficits } \\
- & \begin{array}{l}\text { Reverted the increase of } \\
\text { proinflammatory cytokines }\end{array} \\
\text { - } & \begin{array}{l}\text { Reversed the oxidative damage } \\
\text { (mitochondrial dysfunction) }\end{array}\end{array}$ & {$[41,97]$} \\
\hline $\begin{array}{l}\mathrm{ICV}-\mathrm{A} \beta 25-35 \\
\text { (mouse) }\end{array}$ & $\begin{array}{l}\text { Injection of } \\
\mathrm{A} \beta 25-35\end{array}$ & $\begin{array}{l}\text { rhEPO or } \\
\text { Neuro-EPO }\end{array}$ & $\begin{array}{l}\text { Dose used } 1250, \\
2500 \text { and } 5000 \\
\mathrm{UI} / \mathrm{kg} \text { once a day or } \\
62,125 \text { and } \\
250 \mathrm{IU} / \mathrm{kg} \text { three } \\
\text { times a day; i.p and } \\
\text { i.n (respectively) }\end{array}$ & $\begin{array}{l}\text { - } \\
\text { Neuronal loss in the } \\
\text { hippocampal CA1 region } \\
\text { is prevented } \\
\text { - } \quad \text { Improved learning deficits } \\
\text { Reduced the number of brain } \\
\text { amyloid plaques } \\
\text { - } \quad \text { Neuro- EPO treatment blocks } \\
\text { both intrinsic and extrinsic } \\
\text { apoptotic pathways } \\
\text { - } \quad \begin{array}{l}\text { Prevented the increased levels } \\
\text { of TNF- } \alpha \text { and IL-1 } \beta\end{array} \\
\text { - } \\
\text { Reduced the oxidative effects } \\
\text { (membrane lipid peroxidation) }\end{array}$ & {$[40,101]$} \\
\hline $\begin{array}{l}\operatorname{Tg} 2576^{*} \\
\text { (mouse) }\end{array}$ & $\begin{array}{l}\text { Overexpression } \\
\text { of human APP } \\
\text { (Swedish } \\
\text { double } \\
\text { mutation) }\end{array}$ & $\begin{array}{l}\text { rhEPO } \\
\text { or } \\
\text { Neuro-EPO }\end{array}$ & $\begin{array}{l}\text { Dose used } \\
5000 \mathrm{IU} / \mathrm{kg} \text { once a } \\
\text { day for five days or } \\
125 \text { and } 250 \mathrm{IU} / \mathrm{kg}, \\
\text { three times a week } \\
\text { for } 2 \text { months; i.p } \\
\text { and i.n } \\
\text { (respectively) }\end{array}$ & $\begin{array}{ll}\text { - } & \text { Improved contextual memory } \\
\text { and synaptophysin expression } \\
\text { - }\end{array} \begin{array}{l}\text { Reduced } \\
\text { endothelial dysfunction } \\
\text { - } \quad \begin{array}{l}\text { Reduced the amount of } \mathrm{A} \beta \\
\text { plaques in the brain }\end{array} \\
\text { - } \quad \text { Reduced glial activation } \\
\text { - } \quad \text { - Reduced the oxidative effects } \\
\text { (membrane lipid peroxidation) }\end{array}$ & {$[72,101]$} \\
\hline
\end{tabular}

\section{5. rhEPO Evidence in Human Trials with Alzheimer's Disease}

As we explained before, the neuroprotective effect of rhEPO has been confirmed in different experimental models, however, the evidence in patients with cognitive impairment is scarce [46,74,163-167]. Some existing reports indicate that the level of EPO in the brain and CSF may increase with aging [28,32]. However, EPO levels in AD patients have been reported to be low, while EPOR levels are high [15]. This is considered a failure of the intrinsic EPO/EPOR protection system due to a shortage of cytokines [75,142]. EPO is an important molecule for cell protection in different pathologies; therefore, its use is being evaluated in clinical trials $[13,39,43,146,168-171]$.

Unfortunately, there are few clinical studies on the effects of rhEPO administration in patients with $\mathrm{AD}$, which have focused on the treatment of dementia symptoms and scarcely diminish the presence of characteristic hallmarks (A $\beta$ and tau-p aggregation) of this pathology [172-175]. Even so, preliminary studies have shown that rhEPO administration in AD patients can help regulate the elevated levels of $A \beta$ and tau-p proteins. They also demonstrated tissue protection and behavioral 
improvement in most cases $[74,142,175,176]$. Although there is no clear evidence of the anti-apoptotic effect of rhEPO in clinical trials with $A D$, other pathological studies involving $A \beta$ or tau proteins also show positive results. For example, data obtained from a study of human neonates with hypoxic-ischemic encephalopathy (HIE) showed that elevated serum levels of tau were clearly reduced to nearly normal conditions after rhEPO treatment (200 IU/kg, intravenously) once a day for ten consecutive days [146]. Similarly, clinical studies in patients with chronic kidney disease (CKD) and cognitive dysfunction reported that abnormally elevated levels of $A \beta$, GSK3- $\beta$ and tau-p, among others, were reestablished after treatment with rhEPO (100 IU $/ \mathrm{kg})$ administered twice weekly for 6 months [134]. These findings suggest that rhEPO improves the neurological outcome of neonatal behavior and enhances the neuropsychological assessment of adult patients, respectively $[134,146]$. Finally, although there is little evidence on the anti-inflammatory effects of rhEPO in AD patients, some clinical studies have reported that the inhibition of pro-inflammatory molecules such as TNF- $\alpha$ [177], the increase in HIF [142], and even some related effects with exogenous EPO molecules, could be considered as potential treatments for neurodegenerative diseases [22,76,178]. However, some of the data obtained are refuted due to differences in human clinical trials, such as differences between experimental protocols (application route, concentration and number of rhEPO doses), patient inclusion criteria (differential diagnosis of disease and age), small study groups, short follow-up periods, and interpretation of results. This situation, among others, increases the variability of the results, therefore, they must be carefully analyzed.

\section{Conclusions}

Researchers in the field of neuroscience are increasingly proposing that the protective effects of rhEPO and its molecular variants could be used as an alternative to treat neurodegenerative disorders as $\mathrm{AD}$ itself. According to the data described in this narrative review, the reinforcement of the endogenous EPO/EPOR system by exogenous EPO molecules may be crucial in protecting the brain against neurological damage caused by abnormal $\mathrm{A} \beta$ and tau-p aggregates or other pathological stimuli that promote the neurodegeneration in $\mathrm{AD}$ (Figure 5). This is based on extensive evidence that the EPO molecule can act directly or indirectly over abnormal protein aggregates, avoiding their formation and diminishing their load during disease progression. However, the mechanisms that promote and regulate the protective effect (anti-apoptotic, anti-inflammatory, antioxidant and anti-excitotoxic) in the AD models are not totally clear. For this and other reasons, the EPO/EPOR system deserves further investigation to better understand its role as pharmacological agent. Finally, we believe that pleiotropic function of rhEPO and its molecular variants in the CNS, not only for neurological diseases, can be explained through functional receptor-mediated differential cellular response and not only by the kind of EPO molecule. For these reasons, studies should be directed towards the contributions of EPORs, since the expression of specific types of receptors determines the cellular response, although it may not only be receptor- or cell-dependent, but also subject to the pathophysiological conditions found in the brain of patients undergoing any neurological disease such as AD. 


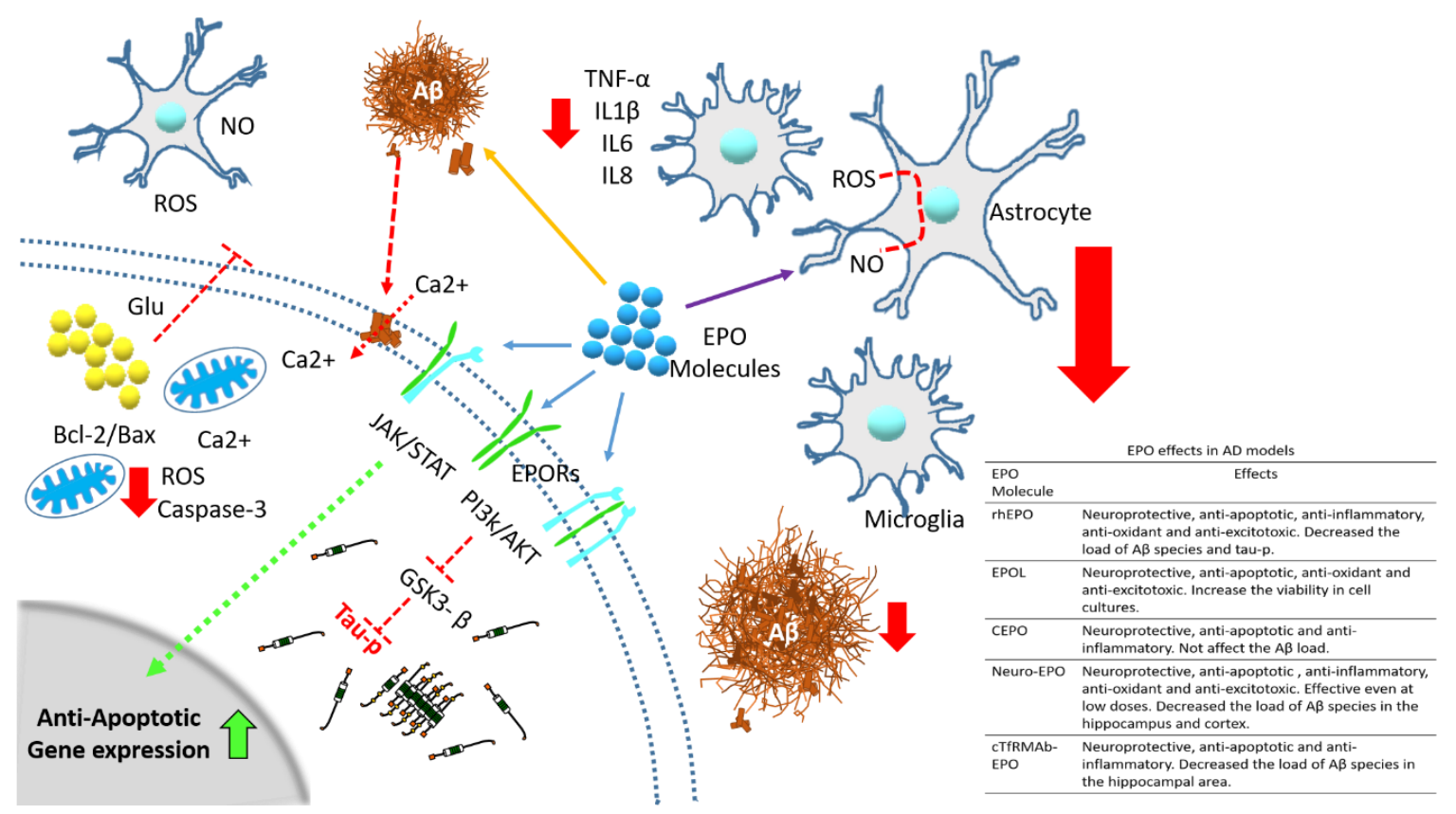

Figure 5. Protective effects of rhEPO and its molecular variants against the damages produced by the abnormal accumulation of proteins (A $\beta$ and tau-p) analyzed in different models of AD. The rhEPO or its molecular variants through of the interaction with its receptor (different complex of them) (blue arrows) they activate molecular pathways (such as PI3K/AKT or JAK/STAT) responsible for decreasing the abnormal cellular processes such as apoptotic gene expression (dotted green arrow and solid green arrow into nucleus), caspase-3 activation (red arrow), release of Glu (dotted red line), over activation of GSK3- $\beta$ (dotted red line) all them inside the cell and cytokines production (red arrow) outside of cell, among others, associated with cellular damages by apoptosis, oxidative stress and excitotoxicity. In addition, have been proposed that the exogenous EPO molecules also may avoid the aggregation of $\mathrm{A} \beta$ (yellow arrow) and tau-p through to join with them and decreasing their load in brains during AD progression. The pathological mechanism in this disease also involve the participation of glial cells, responsible to increase the level of free radical and pro-inflammatory cytokines and inducing neuronal cell death, although they are also regulated by the EPO/EPOR protective system (purple arrow). Red big arrows refer to decreased cellular alterations by EPO treatment.

Author Contributions: J.J.J.-B. and M.C.R.-C.: responsible for the conception and design of this review. D.G.-M. and C.B.-Z.: integration and interpretation of information. D.G.-M. and F.G.-S.: critically editing and revising this work and contributing important intellectual content. The images in Figures 1, 3 and 5 were generated by Y.G.-M. The images in the Figures 2 and 4 were generated by D.G.-M. All authors have read and agreed to the published version of the manuscript.

Funding: This research received no external funding.

Acknowledgments: This work was supported by the Guadalajara University program (Pro-SNI 2019 \#248845 and p3e \#250278). G.S was supported by Conacyt-Mexico (grant \#255224) and SEP-CINVESTAV (grant 73). Proofread by Modern Manuscript Editing Services.

Conflicts of Interest: The authors declare no conflict of interest.

\section{References}

1. Cummings, J.; Zhong, K. Biomarker-driven therapeutic management of alzheimer's disease: Establishing the foundations. Clin. Pharmacol. Ther. 2014, 95, 67-77. [CrossRef] [PubMed]

2. Mattson, M.P. Pathways towards and away from alzheimer's disease. Nature 2004, 430, 631-639. [CrossRef] [PubMed]

3. Selkoe, D.J. Alzheimer's disease results from the cerebral accumulation and cytotoxicity of amyloid beta-protein. J. Alzheimers Dis. 2001, 3, 75-80. [CrossRef] [PubMed] 
4. Selkoe, D.J. The molecular pathology of alzheimer's disease. Neuron 1991, 6, 487-498. [CrossRef]

5. Hyman, B.T.; Gomez-Isla, T. The natural history of alzheimer neurofibrillary tangles and amyloid deposits. Neurobiol. Aging 1997, 18, 386-387. [CrossRef]

6. Hardy, J.; Selkoe, D.J. The amyloid hypothesis of alzheimer's disease: Progress and problems on the road to therapeutics. Science 2002, 297, 353-356. [CrossRef]

7. Walsh, D.M.; Klyubin, I.; Fadeeva, J.V.; Rowan, M.J.; Selkoe, D.J. Amyloid-beta oligomers: Their production, toxicity and therapeutic inhibition. Biochem. Soc. Trans. 2002, 30, 552-557. [CrossRef]

8. Trojanowski, J.Q.; Lee, V.M. Phosphorylation of paired helical filament tau in alzheimer's disease neurofibrillary lesions: Focusing on phosphatases. FASEB J. 1995, 9, 1570-1576. [CrossRef]

9. Gomez-Isla, T.; Hollister, R.; West, H.; Mui, S.; Growdon, J.H.; Petersen, R.C.; Parisi, J.E.; Hyman, B.T. Neuronal loss correlates with but exceeds neurofibrillary tangles in alzheimer's disease. Ann. Neurol. 1997, 41, 17-24. [CrossRef]

10. Braak, H.; Braak, E. Staging of alzheimer's disease-related neurofibrillary changes. Neurobiol. Aging 1995, 16, 271-278; discussion 278-284. [CrossRef]

11. Basurto-Islas, G.; Luna-Munoz, J.; Guillozet-Bongaarts, A.L.; Binder, L.I.; Mena, R.; Garcia-Sierra, F. Accumulation of aspartic acid421- and glutamic acid391-cleaved tau in neurofibrillary tangles correlates with progression in alzheimer disease. J. Neuropathol. Exp. Neurol. 2008, 67, 470-483. [CrossRef] [PubMed]

12. Fisher, J.W. Erythropoietin: Physiology and pharmacology update. Exp. Biol. Med. 2003, 228, 1-14. [CrossRef] [PubMed]

13. Ehrenreich, H.; Aust, C.; Krampe, H.; Jahn, H.; Jacob, S.; Herrmann, M.; Siren, A.L. Erythropoietin: Novel approaches to neuroprotection in human brain disease. Metab. Brain Dis. 2004, 19, 195-206. [CrossRef] [PubMed]

14. Konishi, Y.; Chui, D.H.; Hirose, H.; Kunishita, T.; Tabira, T. Trophic effect of erythropoietin and other hematopoietic factors on central cholinergic neurons in vitro and in vivo. Brain Res. 1993, 609, $29-35$. [CrossRef]

15. Assaraf, M.I.; Diaz, Z.; Liberman, A.; Miller, W.H., Jr.; Arvanitakis, Z.; Li, Y.; Bennett, D.A.; Schipper, H.M. Brain erythropoietin receptor expression in alzheimer disease and mild cognitive impairment. J. Neuropathol. Exp. Neurol. 2007, 66, 389-398. [CrossRef]

16. Brines, M.L.; Ghezzi, P.; Keenan, S.; Agnello, D.; de Lanerolle, N.C.; Cerami, C.; Itri, L.M.; Cerami, A. Erythropoietin crosses the blood-brain barrier to protect against experimental brain injury. Proc. Natl. Acad. Sci. USA 2000, 97, 10526-10531. [CrossRef] [PubMed]

17. Juul, S.E.; Anderson, D.K.; Li, Y.; Christensen, R.D. Erythropoietin and erythropoietin receptor in the developing human central nervous system. Pediatr. Res. 1998, 43, 40-49. [CrossRef]

18. Marti, H.H. Erythropoietin and the hypoxic brain. J. Exp. Biol. 2004, 207, 3233-3242. [CrossRef]

19. Morishita, E.; Masuda, S.; Nagao, M.; Yasuda, Y.; Sasaki, R. Erythropoietin receptor is expressed in rat hippocampal and cerebral cortical neurons, and erythropoietin prevents in vitro glutamate-induced neuronal death. Neuroscience 1997, 76, 105-116. [CrossRef]

20. Maiese, K.; Li, F.; Chong, Z.Z. New avenues of exploration for erythropoietin. JAMA 2005, 293, 90-95. [CrossRef]

21. Sugawa, M.; Sakurai, Y.; Ishikawa-Ieda, Y.; Suzuki, H.; Asou, H. Effects of erythropoietin on glial cell development; oligodendrocyte maturation and astrocyte proliferation. Neurosci. Res. 2002, 44, 391-403. [CrossRef]

22. Eid, T.; Brines, M. Recombinant human erythropoietin for neuroprotection: What is the evidence? Clin. Breast. Cancer 2002, 3 (Suppl. 3), S109-S115. [CrossRef]

23. Maiese, K.; Li, F.; Chong, Z.Z. Erythropoietin in the brain: Can the promise to protect be fulfilled? Trends. Pharmacol. Sci. 2004, 25, 577-583. [CrossRef] [PubMed]

24. Obara, N.; Imagawa, S.; Nakano, Y.; Suzuki, N.; Yamamoto, M.; Nagasawa, T. Suppression of erythropoietin gene expression by cadmium depends on inhibition of hif-1, not stimulation of gata-2. Arch. Toxicol. 2003, 77, 267-273. [CrossRef]

25. van der Kooij, M.A.; Groenendaal, F.; Kavelaars, A.; Heijnen, C.J.; van Bel, F. Combination of deferoxamine and erythropoietin: Therapy for hypoxia-ischemia-induced brain injury in the neonatal rat? Neurosci. Lett. 2009, 451, 109-113. [CrossRef] [PubMed] 
26. Genc, S.; Koroglu, T.F.; Genc, K. Erythropoietin as a novel neuroprotectant. Restor. Neurol. Neurosci. 2004, 22, 105-119.

27. Jelkmann, W. Biology of erythropoietin. Clin. Investig. 1994, 72, S3-S10.

28. Brettschneider, J.; Widl, K.; Ehrenreich, H.; Riepe, M.; Tumani, H. Erythropoietin in the cerebrospinal fluid in neurodegenerative diseases. Neurosci. Lett. 2006, 404, 347-351. [CrossRef]

29. Chung, Y.H.; Joo, K.M.; Kim, Y.S.; Lee, K.H.; Lee, W.B.; Cha, C.I. Enhanced expression of erythropoietin in the central nervous system of sod1(g93a) transgenic mice. Brain Res. 2004, 1016, 272-280. [CrossRef]

30. Juul, S.E.; Stallings, S.A.; Christensen, R.D. Erythropoietin in the cerebrospinal fluid of neonates who sustained cns injury. Pediatr. Res. 1999, 46, 543-547. [CrossRef]

31. Siren, A.L.; Knerlich, F.; Poser, W.; Gleiter, C.H.; Bruck, W.; Ehrenreich, H. Erythropoietin and erythropoietin receptor in human ischemic/hypoxic brain. Acta. Neuropathol. 2001, 101, 271-276. [CrossRef] [PubMed]

32. Widl, K.; Brettschneider, J.; Schattauer, D.; Sussmuth, S.; Huber, R.; Ludolph, A.C.; Tumani, H. Erythropoietin in cerebrospinal fluid: Age-related reference values and relevance in neurological disease. Neurochem. Res. 2007, 32, 1163-1168. [CrossRef] [PubMed]

33. Marti, H.H.; Wenger, R.H.; Rivas, L.A.; Straumann, U.; Digicaylioglu, M.; Henn, V.; Yonekawa, Y.; Bauer, C.; Gassmann, M. Erythropoietin gene expression in human, monkey and murine brain. Eur. J. Neurosci. 1996, 8, 666-676. [CrossRef] [PubMed]

34. Nakamura, T.; Ebihara, I.; Shimada, N.; Koide, H. Elevated levels of erythropoietin in cerebrospinal fluid of depressed patients. Am. J. Med. Sci. 1998, 315, 199-201.

35. Bernaudin, M.; Nedelec, A.S.; Divoux, D.; MacKenzie, E.T.; Petit, E.; Schumann-Bard, P. Normobaric hypoxia induces tolerance to focal permanent cerebral ischemia in association with an increased expression of hypoxia-inducible factor- 1 and its target genes, erythropoietin and vegf, in the adult mouse brain. J. Cereb. Blood Flow Metab. 2002, 22, 393-403. [CrossRef]

36. Prass, K.; Scharff, A.; Ruscher, K.; Lowl, D.; Muselmann, C.; Victorov, I.; Kapinya, K.; Dirnagl, U.; Meisel, A. Hypoxia-induced stroke tolerance in the mouse is mediated by erythropoietin. Stroke 2003, 34, 1981-1986. [CrossRef]

37. Urena-Guerrero, M.E.; Castaneda-Cabral, J.L.; Rivera-Cervantes, M.C.; Macias-Velez, R.J.; Jarero-Basulto, J.J.; Gudino-Cabrera, G.; Beas-Zarate, C. Neuroprotective and neurestorative effects of epo and vegf: Perspectives for new therapeutic approaches to neurological diseases. Curr. Pharm. Des. 2020, 26, 1263-1276. [CrossRef]

38. Genc, S.; Akhisaroglu, M.; Kuralay, F.; Genc, K. Erythropoietin restores glutathione peroxidase activity in 1-methyl-4-phenyl-1,2,5,6-tetrahydropyridine-induced neurotoxicity in c57bl mice and stimulates murine astroglial glutathione peroxidase production in vitro. Neurosci. Lett. 2002, 321, 73-76. [CrossRef]

39. Fessel, W.J. Concordance of several subcellular interactions initiates alzheimer's dementia: Their reversal requires combination treatment. Am. J. Alzheimers Dis. Demen. 2017, 32, 166-181. [CrossRef]

40. Maurice, T.; Mustafa, M.H.; Desrumaux, C.; Keller, E.; Naert, G.; Garcia-Barcelo, M.D.; Rodríguez Cruz, Y.; Garcia Rodríguez, J.C. Intranasal formulation of erythropoietin (epo) showed potent protective activity against amyloid toxicity in the abeta(2)(5)(-)(3)(5) non-transgenic mouse model of alzheimer's disease. J. Psychopharmacol. 2013, 27, 1044-1057. [CrossRef]

41. Cevik, B.; Solmaz, V.; Yigitturk, G.; Cavusoglu, T.; Peker, G.; Erbas, O. Neuroprotective effects of erythropoietin on alzheimer's dementia model in rats. Adv. Clin. Exp. Med. 2017, 26, 23-29. [CrossRef] [PubMed]

42. Hamidi, G.; Arabpour, Z.; Shabrang, M.; Rashidi, B.; Alaei, H.; Sharifi, M.R.; Salami, M.; Reisi, P. Erythropoietin improves spatial learning and memory in streptozotocin model of dementia. Pathophysiology 2013, 20, 153-158. [CrossRef] [PubMed]

43. Brines, M.; Grasso, G.; Fiordaliso, F.; Sfacteria, A.; Ghezzi, P.; Fratelli, M.; Latini, R.; Xie, Q.W.; Smart, J.; Su-Rick, C.J.; et al. Erythropoietin mediates tissue protection through an erythropoietin and common beta-subunit heteroreceptor. Proc. Natl. Acad. Sci. USA 2004, 101, 14907-14912. [CrossRef] [PubMed]

44. Leist, M.; Ghezzi, P.; Grasso, G.; Bianchi, R.; Villa, P.; Fratelli, M.; Savino, C.; Bianchi, M.; Nielsen, J.; Gerwien, J.; et al. Derivatives of erythropoietin that are tissue protective but not erythropoietic. Science 2004, 305, 239-242. [CrossRef]

45. Um, M.; Gross, A.W.; Lodish, H.F. A "classical" homodimeric erythropoietin receptor is essential for the antiapoptotic effects of erythropoietin on differentiated neuroblastoma sh-sy5y and pheochromocytoma pc-12 cells. Cell Signal. 2007, 19, 634-645. [CrossRef] 
46. Ehrenreich, H.; Hasselblatt, M.; Dembowski, C.; Cepek, L.; Lewczuk, P.; Stiefel, M.; Rustenbeck, H.H.; Breiter, N.; Jacob, S.; Knerlich, F.; et al. Erythropoietin therapy for acute stroke is both safe and beneficial. Mol. Med. 2002, 8, 495-505. [CrossRef]

47. Lewczuk, P.; Hasselblatt, M.; Kamrowski-Kruck, H.; Heyer, A.; Unzicker, C.; Siren, A.L.; Ehrenreich, H. Survival of hippocampal neurons in culture upon hypoxia: Effect of erythropoietin. Neuroreport 2000, 11, 3485-3488. [CrossRef]

48. Siren, A.L.; Fratelli, M.; Brines, M.; Goemans, C.; Casagrande, S.; Lewczuk, P.; Keenan, S.; Gleiter, C.; Pasquali, C.; Capobianco, A.; et al. Erythropoietin prevents neuronal apoptosis after cerebral ischemia and metabolic stress. Proc. Natl. Acad. Sci. USA 2001, 98, 4044-4049. [CrossRef]

49. Subiros, N.; Del Barco, D.G.; Coro-Antich, R.M. Erythropoietin: Still on the neuroprotection road. Ther. Adv. Neurol. Disord. 2012, 5, 161-173. [CrossRef]

50. Osredkar, D.; Sall, J.W.; Bickler, P.E.; Ferriero, D.M. Erythropoietin promotes hippocampal neurogenesis in in vitro models of neonatal stroke. Neurobiol. Dis. 2010, 38, 259-265. [CrossRef]

51. Erbayraktar, S.; Grasso, G.; Sfacteria, A.; Xie, Q.W.; Coleman, T.; Kreilgaard, M.; Torup, L.; Sager, T.; Erbayraktar, Z.; Gokmen, N.; et al. Asialoerythropoietin is a nonerythropoietic cytokine with broad neuroprotective activity in vivo. Proc. Natl. Acad. Sci. USA 2003, 100, 6741-6746. [CrossRef] [PubMed]

52. Wang, X.; Zhu, C.; Wang, X.; Gerwien, J.G.; Schrattenholz, A.; Sandberg, M.; Leist, M.; Blomgren, K. The nonerythropoietic asialoerythropoietin protects against neonatal hypoxia-ischemia as potently as erythropoietin. J. Neurochem. 2004, 91, 900-910. [CrossRef] [PubMed]

53. Villa, P.; Bigini, P.; Mennini, T.; Agnello, D.; Laragione, T.; Cagnotto, A.; Viviani, B.; Marinovich, M.; Cerami, A.; Coleman, T.R.; et al. Erythropoietin selectively attenuates cytokine production and inflammation in cerebral ischemia by targeting neuronal apoptosis. J. Exp. Med. 2003, 198, 971-975. [CrossRef]

54. Schmidt, R.E.; Green, K.G.; Feng, D.; Dorsey, D.A.; Parvin, C.A.; Lee, J.M.; Xiao, Q.; Brines, M. Erythropoietin and its carbamylated derivative prevent the development of experimental diabetic autonomic neuropathy in stz-induced diabetic nod-scid mice. Exp. Neurol. 2008, 209, 161-170. [CrossRef] [PubMed]

55. Castillo, C.; Zaror, S.; Gonzalez, M.; Hidalgo, A.; Burgos, C.F.; Cabezas, O.I.; Hugues, F.; Jimenez, S.P.; Gonzalez-Horta, E.; Gonzalez-Chavarria, I.; et al. Neuroprotective effect of a new variant of epo nonhematopoietic against oxidative stress. Redox. Biol. 2018, 14, 285-294. [CrossRef]

56. Castillo, C.; Fernandez-Mendivil, C.; Buendia, I.; Saavedra, P.; Meza, C.; Parra, N.C.; Lopez, M.G.; Toledo, J.R.; Fuentealba, J. Neuroprotective effects of epol against oxidative stress induced by soluble oligomers of abeta peptide. Redox. Biol. 2019, 24, 101187. [CrossRef]

57. Garcia-Rodriguez, J.C.; Sosa-Teste, I. The nasal route as a potential pathway for delivery of erythropoietin in the treatment of acute ischemic stroke in humans. ScientificWorldJournal 2009, 9, 970-981. [CrossRef]

58. Rodriguez Cruz, Y.; Mengana Tamos, Y.; Munoz Cernuda, A.; Subiros Martines, N.; Gonzalez-Quevedo, A.; Sosa Teste, I.; Garcia Rodriguez, J.C. Treatment with nasal neuro-epo improves the neurological, cognitive, and histological state in a gerbil model of focal ischemia. ScientificWorldJournal 2010, 10, 2288-2300. [CrossRef]

59. Chang, R.; Al Maghribi, A.; Vanderpoel, V.; Vasilevko, V.; Cribbs, D.H.; Boado, R.; Pardridge, W.M.; Sumbria, R.K. Brain penetrating bifunctional erythropoietin-transferrin receptor antibody fusion protein for alzheimer's disease. Mol. Pharm. 2018, 15, 4963-4973. [CrossRef]

60. Biebl, M.; Cooper, C.M.; Winkler, J.; Kuhn, H.G. Analysis of neurogenesis and programmed cell death reveals a self-renewing capacity in the adult rat brain. Neurosci. Lett. 2000, 291, 17-20. [CrossRef]

61. Cras, P.; Smith, M.A.; Richey, P.L.; Siedlak, S.L.; Mulvihill, P.; Perry, G. Extracellular neurofibrillary tangles reflect neuronal loss and provide further evidence of extensive protein cross-linking in alzheimer disease. Acta. Neuropathol. 1995, 89, 291-295. [CrossRef] [PubMed]

62. Mosconi, L.; Herholz, K.; Prohovnik, I.; Nacmias, B.; De Cristofaro, M.T.; Fayyaz, M.; Bracco, L.; Sorbi, S.; Pupi, A. Metabolic interaction between apoe genotype and onset age in alzheimer's disease: Implications for brain reserve. J. Neurol. Neurosurg. Psychiatry. 2005, 76, 15-23. [CrossRef] [PubMed]

63. Li, G.; Ma, R.; Huang, C.; Tang, Q.; Fu, Q.; Liu, H.; Hu, B.; Xiang, J. Protective effect of erythropoietin on beta-amyloid-induced pc12 cell death through antioxidant mechanisms. Neurosci. Lett. 2008, 442, 143-147. [CrossRef] [PubMed]

64. Shang, Y.C.; Chong, Z.Z.; Hou, J.; Maiese, K. The forkhead transcription factor foxo3a controls microglial inflammatory activation and eventual apoptotic injury through caspase 3. Curr. Neurovasc. Res. 2009, 6, 20-31. [CrossRef] [PubMed] 
65. Sepulveda, F.J.; Fierro, H.; Fernandez, E.; Castillo, C.; Peoples, R.W.; Opazo, C.; Aguayo, L.G. Nature of the neurotoxic membrane actions of amyloid-beta on hippocampal neurons in alzheimer's disease. Neurobiol. Aging 2014, 35, 472-481. [CrossRef] [PubMed]

66. Saez-Orellana, F.; Godoy, P.A.; Bastidas, C.Y.; Silva-Grecchi, T.; Guzman, L.; Aguayo, L.G.; Fuentealba, J. Atp leakage induces p2xr activation and contributes to acute synaptic excitotoxicity induced by soluble oligomers of beta-amyloid peptide in hippocampal neurons. Neuropharmacology 2016, 100, 116-123. [CrossRef]

67. Zempel, H.; Thies, E.; Mandelkow, E.; Mandelkow, E.M. Abeta oligomers cause localized ca(2+) elevation, missorting of endogenous tau into dendrites, tau phosphorylation, and destruction of microtubules and spines. J. Neurosci. 2010, 30, 11938-11950. [CrossRef]

68. Sepulveda, F.J.; Parodi, J.; Peoples, R.W.; Opazo, C.; Aguayo, L.G. Synaptotoxicity of alzheimer beta amyloid can be explained by its membrane perforating property. PLoS ONE 2010, 5, e11820. [CrossRef]

69. Fuchsberger, T.; Martinez-Bellver, S.; Giraldo, E.; Teruel-Marti, V.; Lloret, A.; Vina, J. Abeta induces excitotoxicity mediated by apc/c-cdh1 depletion that can be prevented by glutaminase inhibition promoting neuronal survival. Sci. Rep. 2016, 6, 31158. [CrossRef]

70. Kumar, A.; Singh, A. A review on alzheimer's disease pathophysiology and its management: An update. Pharmacol. Rep. 2015, 67, 195-203. [CrossRef]

71. Maiese, K.; Chong, Z.Z.; Hou, J.; Shang, Y.C. New strategies for alzheimer's disease and cognitive impairment. Oxid. Med. Cell. Longev. 2009, 2, 279-289. [CrossRef] [PubMed]

72. Lee, S.T.; Chu, K.; Park, J.E.; Jung, K.H.; Jeon, D.; Lim, J.Y.; Lee, S.K.; Kim, M.; Roh, J.K. Erythropoietin improves memory function with reducing endothelial dysfunction and amyloid-beta burden in alzheimer's disease models. J. Neurochem. 2012, 120, 115-124. [CrossRef] [PubMed]

73. Park, M.H.; Lee, S.M.; Lee, J.W.; Son, D.J.; Moon, D.C.; Yoon, D.Y.; Hong, J.T. Erk-mediated production of neurotrophic factors by astrocytes promotes neuronal stem cell differentiation by erythropoietin. Biochem. Biophys. Res. Commun. 2006, 339, 1021-1028. [CrossRef] [PubMed]

74. Vinothkumar, G.; Krishnakumar, S.; Shivashekar, G.; Sreedhar, S.; Dinesh, S.; Sundaram, A.; Balakrishnan, D.; Venkataraman, P. Therapeutic impact of rhuepo on abnormal platelet app, bace 1, presenilin 1, adam 10 and abeta expressions in chronic kidney disease patients with cognitive dysfunction like alzheimer's disease: A pilot study. Biomed. Pharmacother. 2018, 104, 211-222.

75. Cerami, A.; Brines, M.; Ghezzi, P.; Cerami, C.; Itri, L.M. Neuroprotective properties of epoetin alfa. Nephrol. Dial. Transplant. 2002, 17 (Suppl. 1), 8-12. [CrossRef]

76. Agnello, D.; Bigini, P.; Villa, P.; Mennini, T.; Cerami, A.; Brines, M.L.; Ghezzi, P. Erythropoietin exerts an anti-inflammatory effect on the cns in a model of experimental autoimmune encephalomyelitis. Brain Res. 2002, 952, 128-134. [CrossRef]

77. Pregi, N.; Wenker, S.; Vittori, D.; Leiros, C.P.; Nesse, A. Tnf-alpha-induced apoptosis is prevented by erythropoietin treatment on sh-sy5y cells. Exp. Cell Res. 2009, 315, 419-431. [CrossRef]

78. Ma, C.; Cheng, F.; Wang, X.; Zhai, C.; Yue, W.; Lian, Y.; Wang, Q. Erythropoietin pathway: A potential target for the treatment of depression. Int. J. Mol. Sci. 2016, 17, 677. [CrossRef]

79. Ma, R.; Xiong, N.; Huang, C.; Tang, Q.; Hu, B.; Xiang, J.; Li, G. Erythropoietin protects pc12 cells from beta-amyloid(25-35)-induced apoptosis via pi3k/akt signaling pathway. Neuropharmacology 2009, 56, 1027-1034. [CrossRef]

80. Kilic, E.; Kilic, U.; Soliz, J.; Bassetti, C.L.; Gassmann, M.; Hermann, D.M. Brain-derived erythropoietin protects from focal cerebral ischemia by dual activation of erk-1/-2 and akt pathways. FASEB J. 2005, 19, 2026-2028. [CrossRef]

81. Chong, Z.Z.; Kang, J.Q.; Maiese, K. Erythropoietin is a novel vascular protectant through activation of akt1 and mitochondrial modulation of cysteine proteases. Circulation 2002, 106, 2973-2979. [CrossRef] [PubMed]

82. Lee, S.; Suh, Y.H.; Kim, S.; Kim, Y. Comparison of the structures of beta amyloid peptide (25-35) and substance $\mathrm{p}$ in trifluoroethanol/water solution. J. Biomol. Struct. Dyn. 1999, 17, 381-391. [CrossRef] [PubMed]

83. Kubo, T.; Nishimura, S.; Oda, T. Amyloid beta-peptide alters the distribution of early endosomes and inhibits phosphorylation of akt in the presence of 3-(4,5-dimethylthiazol-2-yl)-2,5-diphenyltetrazolium bromide (mtt). Brain Res. Mol. Brain Res. 2002, 106, 94-100. [CrossRef]

84. Sun, Z.K.; Yang, H.Q.; Pan, J.; Zhen, H.; Wang, Z.Q.; Chen, S.D.; Ding, J.Q. Protective effects of erythropoietin on tau phosphorylation induced by beta-amyloid. J. Neurosci. Res. 2008, 86, 3018-3027. [CrossRef] 
85. Chong, Z.Z.; Li, F.; Maiese, K. Erythropoietin requires nf-kappab and its nuclear translocation to prevent early and late apoptotic neuronal injury during beta-amyloid toxicity. Curr. Neurovasc. Res. 2005, 2, 387-399. [CrossRef]

86. Zhi-Kun, S.; Hong-Qi, Y.; Zhi-Quan, W.; Jing, P.; Zhen, H.; Sheng-Di, C. Erythropoietin prevents pc12 cells from beta-amyloid-induced apoptosis via pi3kakt pathway. Transl. Neurodegener. 2012, 1, 7. [CrossRef]

87. Ma, R.; Hu, J.; Huang, C.; Wang, M.; Xiang, J.; Li, G. Jak2/stat5/bcl-xl signalling is essential for erythropoietin-mediated protection against apoptosis induced in pc12 cells by the amyloid beta-peptide abeta25-35. Br. J. Pharmacol. 2014, 171, 3234-3245. [CrossRef]

88. Pregi, N.; Vittori, D.; Perez, G.; Leiros, C.P.; Nesse, A. Effect of erythropoietin on staurosporine-induced apoptosis and differentiation of sh-sy5y neuroblastoma cells. Biochim. Biophys. Acta 2006, 1763, 238-246. [CrossRef]

89. Somervaille, T.C.; Linch, D.C.; Khwaja, A. Growth factor withdrawal from primary human erythroid progenitors induces apoptosis through a pathway involving glycogen synthase kinase-3 and bax. Blood 2001, 98, 1374-1381. [CrossRef]

90. Rossig, L.; Badorff, C.; Holzmann, Y.; Zeiher, A.M.; Dimmeler, S. Glycogen synthase kinase-3 couples akt-dependent signaling to the regulation of p21cip1 degradation. J. Biol. Chem. 2002, 277, 9684-9689. [CrossRef]

91. Su, B.; Wang, X.; Nunomura, A.; Moreira, P.I.; Lee, H.G.; Perry, G.; Smith, M.A.; Zhu, X. Oxidative stress signaling in alzheimer's disease. Curr. Alzheimer. Res. 2008, 5, 525-532. [CrossRef] [PubMed]

92. Balaji, V.; Kaniyappan, S.; Mandelkow, E.; Wang, Y.; Mandelkow, E.M. Pathological missorting of endogenous mapt/tau in neurons caused by failure of protein degradation systems. Autophagy 2018, 14, 2139-2154. [CrossRef] [PubMed]

93. Peters, C.; Fernandez-Perez, E.J.; Burgos, C.F.; Espinoza, M.P.; Castillo, C.; Urrutia, J.C.; Streltsov, V.A.; Opazo, C.; Aguayo, L.G. Inhibition of amyloid beta-induced synaptotoxicity by a pentapeptide derived from the glycine zipper region of the neurotoxic peptide. Neurobiol. Aging 2013, 34, 2805-2814. [CrossRef] [PubMed]

94. Garzon, F.; Coimbra, D.; Parcerisas, A.; Rodriguez, Y.; Garcia, J.C.; Soriano, E.; Rama, R. Neuroepo preserves neurons from glutamate-induced excitotoxicity. J. Alzheimers Dis. 2018, 65, 1469-1483. [CrossRef] [PubMed]

95. Reisi, P.; Alaei, H.; Babri, S.; Sharifi, M.R.; Mohaddes, G. Effects of treadmill running on spatial learning and memory in streptozotocin-induced diabetic rats. Neurosci. Lett. 2009, 455, 79-83. [CrossRef]

96. Ishrat, T.; Parveen, K.; Hoda, M.N.; Khan, M.B.; Yousuf, S.; Ansari, M.A.; Saleem, S.; Islam, F. Effects of pycnogenol and vitamin e on cognitive deficits and oxidative damage induced by intracerebroventricular streptozotocin in rats. Behav. Pharmacol. 2009, 20,567-575. [CrossRef]

97. Arabpoor, Z.; Hamidi, G.; Rashidi, B.; Shabrang, M.; Alaei, H.; Sharifi, M.R.; Salami, M.; Dolatabadi, H.R.; Reisi, P. Erythropoietin improves neuronal proliferation in dentate gyrus of hippocampal formation in an animal model of alzheimer's disease. Adv. Biomed. Res. 2012, 1, 50.

98. Mehla, J.; Pahuja, M.; Gupta, Y.K. Streptozotocin-induced sporadic alzheimer's disease: Selection of appropriate dose. J. Alzheimers Dis. 2013, 33, 17-21. [CrossRef]

99. Salkovic-Petrisic, M.; Knezovic, A.; Hoyer, S.; Riederer, P. What have we learned from the streptozotocininduced animal model of sporadic alzheimer's disease, about the therapeutic strategies in alzheimer's research. J. Neural. Transm. 2013, 120, 233-252. [CrossRef]

100. Maurice, T.; Lockhart, B.P.; Privat, A. Amnesia induced in mice by centrally administered beta-amyloid peptides involves cholinergic dysfunction. Brain Res. 1996, 706, 181-193. [CrossRef]

101. Rodriguez Cruz, Y.; Strehaiano, M.; Rodriguez Obaya, T.; Garcia Rodriguez, J.C.; Maurice, T. An intranasal formulation of erythropoietin (neuro-epo) prevents memory deficits and amyloid toxicity in the appswe transgenic mouse model of alzheimer's disease. J. Alzheimers Dis. 2017, 55, 231-248. [CrossRef] [PubMed]

102. Hsiao, K.; Chapman, P.; Nilsen, S.; Eckman, C.; Harigaya, Y.; Younkin, S.; Yang, F.; Cole, G. Correlative memory deficits, abeta elevation, and amyloid plaques in transgenic mice. Science 1996, 274, 99-102. [CrossRef] [PubMed]

103. Borchelt, D.R.; Davis, J.; Fischer, M.; Lee, M.K.; Slunt, H.H.; Ratovitsky, T.; Regard, J.; Copeland, N.G.; Jenkins, N.A.; Sisodia, S.S.; et al. A vector for expressing foreign genes in the brains and hearts of transgenic mice. Genet. Anal. 1996, 13, 159-163. [CrossRef] 
104. Armand-Ugon, M.; Aso, E.; Moreno, J.; Riera-Codina, M.; Sanchez, A.; Vegas, E.; Ferrer, I. Memory improvement in the abetapp/ps1 mouse model of familial alzheimer's disease induced by carbamylated-erythropoietin is accompanied by modulation of synaptic genes. J. Alzheimers Dis. 2015, 45, 407-421. [CrossRef] [PubMed]

105. Modabbernia, A.; Ashrafi, M.; Modabbernia, M.J. Let's try erythropoietin in alzheimer's disease. Med. Hypotheses 2010, 75, 270-271. [CrossRef] [PubMed]

106. Itagaki, S.; McGeer, P.L.; Akiyama, H.; Zhu, S.; Selkoe, D. Relationship of microglia and astrocytes to amyloid deposits of alzheimer disease. J. Neuroimmunol. 1989, 24, 173-182. [CrossRef]

107. Campana, W.M.; Li, X.; Shubayev, V.I.; Angert, M.; Cai, K.; Myers, R.R. Erythropoietin reduces schwann cell tnf-alpha, wallerian degeneration and pain-related behaviors after peripheral nerve injury. Eur. J. Neurosci. 2006, 23, 617-626. [CrossRef]

108. Gunnarson, E.; Song, Y.; Kowalewski, J.M.; Brismar, H.; Brines, M.; Cerami, A.; Andersson, U.; Zelenina, M.; Aperia, A. Erythropoietin modulation of astrocyte water permeability as a component of neuroprotection. Proc. Natl. Acad. Sci. USA 2009, 106, 1602-1607. [CrossRef]

109. Kim, S.M.; Song, J.; Kim, S.; Han, C.; Park, M.H.; Koh, Y.; Jo, S.A.; Kim, Y.Y. Identification of peripheral inflammatory markers between normal control and alzheimer's disease. BMC Neurol. 2011, 11, 51. [CrossRef]

110. Park, J.; Lee, S.Y.; Shon, J.; Kim, K.; Lee, H.J.; Kim, K.A.; Lee, B.Y.; Oh, S.H.; Kim, N.K.; Kim, O.J. Adalimumab improves cognitive impairment, exerts neuroprotective effects and attenuates neuroinflammation in an abeta1-40-injected mouse model of alzheimer's disease. Cytotherapy 2019, 21, 671-682. [CrossRef]

111. Schipper, H.M. Astrocytes, brain aging, and neurodegeneration. Neurobiol. Aging 1996, 17, 467-480. [CrossRef]

112. Chong, Z.Z.; Kang, J.Q.; Maiese, K. Apaf-1, bcl-xl, cytochrome c, and caspase-9 form the critical elements for cerebral vascular protection by erythropoietin. J. Cereb. Blood Flow Metab. 2003, 23, 320-330. [CrossRef] [PubMed]

113. Chong, Z.Z.; Kang, J.Q.; Maiese, K. Metabotropic glutamate receptors promote neuronal and vascular plasticity through novel intracellular pathways. Histol. Histopathol. 2003, 18, 173-189. [PubMed]

114. Naert, G.; Rivest, S. Cc chemokine receptor 2 deficiency aggravates cognitive impairments and amyloid pathology in a transgenic mouse model of alzheimer's disease. J. Neurosci. 2011, 31, 6208-6220. [CrossRef] [PubMed]

115. Nagai, A.; Nakagawa, E.; Choi, H.B.; Hatori, K.; Kobayashi, S.; Kim, S.U. Erythropoietin and erythropoietin receptors in human cns neurons, astrocytes, microglia, and oligodendrocytes grown in culture. J. Neuropathol. Exp. Neurol. 2001, 60, 386-392. [CrossRef] [PubMed]

116. Perry, R.T.; Collins, J.S.; Wiener, H.; Acton, R.; Go, R.C. The role of tnf and its receptors in alzheimer's disease. Neurobiol. Aging 2001, 22, 873-883. [CrossRef]

117. Montgomery, S.L.; Bowers, W.J. Tumor necrosis factor-alpha and the roles it plays in homeostatic and degenerative processes within the central nervous system. J. Neuroimmune. Pharmacol. 2012, 7, 42-59. [CrossRef]

118. Clark, I.; Atwood, C.; Bowen, R.; Paz-Filho, G.; Vissel, B. Tumor necrosis factor-induced cerebral insulin resistance in alzheimer's disease links numerous treatment rationales. Pharmacol. Rev. 2012, 64, 1004-1026. [CrossRef]

119. Yamamoto, M.; Kiyota, T.; Horiba, M.; Buescher, J.L.; Walsh, S.M.; Gendelman, H.E.; Ikezu, T. Interferon-gamma and tumor necrosis factor-alpha regulate amyloid-beta plaque deposition and beta-secretase expression in swedish mutant app transgenic mice. Am. J. Pathol. 2007, 170, 680-692. [CrossRef]

120. Janelsins, M.C.; Mastrangelo, M.A.; Park, K.M.; Sudol, K.L.; Narrow, W.C.; Oddo, S.; LaFerla, F.M.; Callahan, L.M.; Federoff, H.J.; Bowers, W.J. Chronic neuron-specific tumor necrosis factor-alpha expression enhances the local inflammatory environment ultimately leading to neuronal death in $3 x \operatorname{tg}$-ad mice. Am. J. Pathol. 2008, 173, 1768-1782. [CrossRef]

121. Shen, J.; Wu, Y.; Xu, J.Y.; Zhang, J.; Sinclair, S.H.; Yanoff, M.; Xu, G.; Li, W.; Xu, G.T. Erk- and akt-dependent neuroprotection by erythropoietin (epo) against glyoxal-ages via modulation of bcl-xl, bax, and bad. Investig. Ophthalmol. Vis. Sci. 2010, 51, 35-46. [CrossRef] [PubMed] 
122. Akiyama, H.; Barger, S.; Barnum, S.; Bradt, B.; Bauer, J.; Cole, G.M.; Cooper, N.R.; Eikelenboom, P.; Emmerling, M.; Fiebich, B.L.; et al. Inflammation and alzheimer's disease. Neurobiol. Aging 2000, 21, $383-421$. [CrossRef]

123. Horiuchi, T.; Mitoma, H.; Harashima, S.; Tsukamoto, H.; Shimoda, T. Transmembrane tnf-alpha: Structure, function and interaction with anti-tnf agents. Rheumatology 2010, 49, 1215-1228. [CrossRef] [PubMed]

124. Montgomery, S.L.; Mastrangelo, M.A.; Habib, D.; Narrow, W.C.; Knowlden, S.A.; Wright, T.W.; Bowers, W.J. Ablation of tnf-ri/rii expression in alzheimer's disease mice leads to an unexpected enhancement of pathology: Implications for chronic pan-tnf-alpha suppressive therapeutic strategies in the brain. Am. J. Pathol. 2011, 179, 2053-2070. [CrossRef] [PubMed]

125. Hansen, D.V.; Hanson, J.E.; Sheng, M. Microglia in alzheimer's disease. J. Cell Biol. 2018, 217, 459-472. [CrossRef] [PubMed]

126. Su, F.; Bai, F.; Zhang, Z. Inflammatory cytokines and alzheimer's disease: A review from the perspective of genetic polymorphisms. Neurosci. Bull 2016, 32, 469-480. [CrossRef] [PubMed]

127. Noh, M.Y.; Cho, K.A.; Kim, H.; Kim, S.M.; Kim, S.H. Erythropoietin modulates the immune-inflammatory response of a sod1(g93a) transgenic mouse model of amyotrophic lateral sclerosis (als). Neurosci. Lett. 2014, 574, 53-58. [CrossRef]

128. He, F.Q.; Qiu, B.Y.; Li, T.K.; Xie, Q.; Cui, D.J.; Huang, X.L.; Gan, H.T. Tetrandrine suppresses amyloid-beta-induced inflammatory cytokines by inhibiting nf-kappab pathway in murine bv2 microglial cells. Int. Immunopharmacol. 2011, 11, 1220-1225. [CrossRef]

129. Livne-Bar, I.; Lam, S.; Chan, D.; Guo, X.; Askar, I.; Nahirnyj, A.; Flanagan, J.G.; Sivak, J.M. Pharmacologic inhibition of reactive gliosis blocks tnf-alpha-mediated neuronal apoptosis. Cell Death Dis. 2016, 7, e2386. [CrossRef]

130. Neniskyte, U.; Vilalta, A.; Brown, G.C. Tumour necrosis factor alpha-induced neuronal loss is mediated by microglial phagocytosis. FEBS Lett. 2014, 588, 2952-2956. [CrossRef]

131. Shingo, T.; Sorokan, S.T.; Shimazaki, T.; Weiss, S. Erythropoietin regulates the in vitro and in vivo production of neuronal progenitors by mammalian forebrain neural stem cells. J. Neurosci. 2001, 21, 9733-9743. [CrossRef] [PubMed]

132. Chin, K.; Yu, X.; Beleslin-Cokic, B.; Liu, C.; Shen, K.; Mohrenweiser, H.W.; Noguchi, C.T. Production and processing of erythropoietin receptor transcripts in brain. Brain Res. Mol. Brain Res. 2000, 81, $29-42$. [CrossRef]

133. Schipper, H.M. Brain iron deposition and the free radical-mitochondrial theory of ageing. Ageing Res. Rev. 2004, 3, 265-301. [CrossRef] [PubMed]

134. Vinothkumar, G.; Krishnakumar, S.; Venkataraman, P. Correlation between abnormal gsk3beta, beta amyloid, total tau, p-tau 181 levels and neuropsychological assessment total scores in ckd patients with cognitive dysfunction: Impact of rhuepo therapy. J. Clin. Neurosci. 2019, 69, 38-42. [CrossRef] [PubMed]

135. Nicholls, D.G. Mitochondrial calcium function and dysfunction in the central nervous system. Biochim. Biophys. Acta 2009, 1787, 1416-1424. [CrossRef] [PubMed]

136. Butterfield, D.A. Beta-amyloid-associated free radical oxidative stress and neurotoxicity: Implications for alzheimer's disease. Chem. Res. Toxicol. 1997, 10, 495-506. [CrossRef] [PubMed]

137. De Felice, F.G.; Wu, D.; Lambert, M.P.; Fernandez, S.J.; Velasco, P.T.; Lacor, P.N.; Bigio, E.H.; Jerecic, J.; Acton, P.J.; Shughrue, P.J.; et al. Alzheimer's disease-type neuronal tau hyperphosphorylation induced by a beta oligomers. Neurobiol. Aging 2008, 29, 1334-1347. [CrossRef]

138. De Felice, F.G.; Velasco, P.T.; Lambert, M.P.; Viola, K.; Fernandez, S.J.; Ferreira, S.T.; Klein, W.L. Abeta oligomers induce neuronal oxidative stress through an n-methyl-d-aspartate receptor-dependent mechanism that is blocked by the alzheimer drug memantine. J. Biol. Chem. 2007, 282, 11590-11601. [CrossRef]

139. Adamcio, B.; Sargin, D.; Stradomska, A.; Medrihan, L.; Gertler, C.; Theis, F.; Zhang, M.; Muller, M.; Hassouna, I.; Hannke, K.; et al. Erythropoietin enhances hippocampal long-term potentiation and memory. BMC Biol. 2008, 6, 37. [CrossRef]

140. Almaguer-Melian, W.; Merceron-Martinez, D.; Delgado-Ocana, S.; Pavon-Fuentes, N.; Ledon, N.; Bergado, J.A. Epo induces changes in synaptic transmission and plasticity in the dentate gyrus of rats. Synapse 2016, 70, 240-252. [CrossRef]

141. Kumar, R.; Jaggi, A.S.; Singh, N. Effects of erythropoietin on memory deficits and brain oxidative stress in the mouse models of dementia. Korean J. Physiol. Pharmacol. 2010, 14, 345-352. [CrossRef] [PubMed] 
142. Merelli, A.; Czornyj, L.; Lazarowski, A. Erythropoietin: A neuroprotective agent in cerebral hypoxia, neurodegeneration, and epilepsy. Curr. Pharm. Des. 2013, 19, 6791-6801. [CrossRef] [PubMed]

143. Yazihan, N.; Karakurt, O.; Ataoglu, H. Erythropoietin reduces lipopolysaccharide-induced cell damage and midkine secretion in u937 human histiocytic lymphoma cells. Adv. Ther. 2008, 25, 502-514. [CrossRef] [PubMed]

144. Barichello, T.; Simoes, L.R.; Generoso, J.S.; Sangiogo, G.; Danielski, L.G.; Florentino, D.; Dominguini, D.; Comim, C.M.; Petronilho, F.; Quevedo, J. Erythropoietin prevents cognitive impairment and oxidative parameters in wistar rats subjected to pneumococcal meningitis. Transl. Res. 2014, 163, 503-513. [CrossRef] [PubMed]

145. Kumral, A.; Gonenc, S.; Acikgoz, O.; Sonmez, A.; Genc, K.; Yilmaz, O.; Gokmen, N.; Duman, N.; Ozkan, H. Erythropoietin increases glutathione peroxidase enzyme activity and decreases lipid peroxidation levels in hypoxic-ischemic brain injury in neonatal rats. Biol. Neonate 2005, 87, 15-18. [CrossRef]

146. Lv, H.Y.; Wu, S.J.; Wang, Q.L.; Yang, L.H.; Ren, P.S.; Qiao, B.J.; Wang, Z.Y.; Li, J.H.; Gu, X.L.; Li, L.X. Effect of erythropoietin combined with hypothermia on serum tau protein levels and neurodevelopmental outcome in neonates with hypoxic-ischemic encephalopathy. Neural. Regen. Res. 2017, 12, 1655-1663. [PubMed]

147. Bailey, D.M.; Lundby, C.; Berg, R.M.; Taudorf, S.; Rahmouni, H.; Gutowski, M.; Mulholland, C.W.; Sullivan, J.L.; Swenson, E.R.; McEneny, J.; et al. On the antioxidant properties of erythropoietin and its association with the oxidative-nitrosative stress response to hypoxia in humans. Acta. Physiol. 2014, 212, 175-187. [CrossRef]

148. Malhotra, S.; Nijhawan, S.; Rosenbaum, D.M. Erythropoietin (epoetin) as a protective factor for the brain. Curr. Atheroscler. Rep. 2004, 6, 301-306. [CrossRef]

149. Doble, A. The role of excitotoxicity in neurodegenerative disease: Implications for therapy. Pharmacol. Ther. 1999, 81, 163-221. [CrossRef]

150. Prentice, H.; Modi, J.P.; Wu, J.Y. Mechanisms of neuronal protection against excitotoxicity, endoplasmic reticulum stress, and mitochondrial dysfunction in stroke and neurodegenerative diseases. Oxid. Med. Cell. Longev. 2015, 2015, 964518. [CrossRef]

151. Lipton, S.A.; Rosenberg, P.A. Excitatory amino acids as a final common pathway for neurologic disorders. N. Engl. J. Med. 1994, 330, 613-622. [PubMed]

152. Dong, X.X.; Wang, Y.; Qin, Z.H. Molecular mechanisms of excitotoxicity and their relevance to pathogenesis of neurodegenerative diseases. Acta Pharmacol. Sin. 2009, 30, 379-387. [CrossRef] [PubMed]

153. Choi, D.W. Excitotoxic cell death. J. Neurobiol. 1992, 23, 1261-1276. [CrossRef] [PubMed]

154. Stanika, R.I.; Pivovarova, N.B.; Brantner, C.A.; Watts, C.A.; Winters, C.A.; Andrews, S.B. Coupling diverse routes of calcium entry to mitochondrial dysfunction and glutamate excitotoxicity. Proc. Natl. Acad. Sci. USA 2009, 106, 9854-9859. [CrossRef]

155. Lin, M.T.; Beal, M.F. Mitochondrial dysfunction and oxidative stress in neurodegenerative diseases. Nature 2006, 443, 787-795. [CrossRef]

156. Mattson, M.P. Free radicals, calcium, and the synaptic plasticity-cell death continuum: Emerging roles of the transcription factor nf kappa b. Int. Rev. Neurobiol. 1998, 42, 103-168.

157. Sinor, A.D.; Greenberg, D.A. Erythropoietin protects cultured cortical neurons, but not astroglia, from hypoxia and ampa toxicity. Neurosci. Lett. 2000, 290, 213-215. [CrossRef]

158. Sinor, A.D.; Irvin, S.M.; Cobbs, C.S.; Chen, J.; Graham, S.H.; Greenberg, D.A. Hypoxic induction of vascular endothelial growth factor (vegf) protein in astroglial cultures. Brain Res. 1998, 812, 289-291. [CrossRef]

159. Masliah, E.; Alford, M.; DeTeresa, R.; Mallory, M.; Hansen, L. Deficient glutamate transport is associated with neurodegeneration in alzheimer's disease. Ann. Neurol. 1996, 40, 759-766. [CrossRef]

160. Li, S.; Mallory, M.; Alford, M.; Tanaka, S.; Masliah, E. Glutamate transporter alterations in alzheimer disease are possibly associated with abnormal app expression. J. Neuropathol. Exp. Neurol. 1997, 56, 901-911. [CrossRef]

161. Adam-Vizi, V.; Starkov, A.A. Calcium and mitochondrial reactive oxygen species generation: How to read the facts. J. Alzheimers Dis. 2010, 20 (Suppl. 2), S413-S426. [CrossRef]

162. Li, M.X.; Dewson, G. Mitochondria and apoptosis: Emerging concepts. F1000Prime Rep. 2015, 7, 42. [CrossRef] [PubMed]

163. Ehrenreich, H.; Degner, D.; Meller, J.; Brines, M.; Behe, M.; Hasselblatt, M.; Woldt, H.; Falkai, P.; Knerlich, F.; Jacob, S.; et al. Erythropoietin: A candidate compound for neuroprotection in schizophrenia. Mol. Psychiatry 2004, 9, 42-54. [CrossRef] [PubMed] 
164. Haljan, G.; Maitland, A.; Buchan, A.; Arora, R.C.; King, M.; Haigh, J.; Culleton, B.; Faris, P.; Zygun, D. The erythropoietin neuroprotective effect: Assessment in cabg surgery (tenpeaks): A randomized, double-blind, placebo controlled, proof-of-concept clinical trial. Stroke 2009, 40, 2769-2775. [CrossRef] [PubMed]

165. Wiese, L.; Hempel, C.; Penkowa, M.; Kirkby, N.; Kurtzhals, J.A. Recombinant human erythropoietin increases survival and reduces neuronal apoptosis in a murine model of cerebral malaria. Malar J. 2008, 7, 3. [CrossRef]

166. Miskowiak, K.W.; Ehrenreich, H.; Christensen, E.M.; Kessing, L.V.; Vinberg, M. Recombinant human erythropoietin to target cognitive dysfunction in bipolar disorder: A double-blind, randomized, placebo-controlled phase 2 trial. J. Clin. Psychiatry 2014, 75, 1347-1355. [CrossRef]

167. Sargin, D.; Friedrichs, H.; El-Kordi, A.; Ehrenreich, H. Erythropoietin as neuroprotective and neuroregenerative treatment strategy: Comprehensive overview of 12 years of preclinical and clinical research. Best Pract. Res. Clin. Anaesthesiol. 2010, 24, 573-594. [CrossRef]

168. Ehrenreich, H.; Hinze-Selch, D.; Stawicki, S.; Aust, C.; Knolle-Veentjer, S.; Wilms, S.; Heinz, G.; Erdag, S.; Jahn, H.; Degner, D.; et al. Improvement of cognitive functions in chronic schizophrenic patients by recombinant human erythropoietin. Mol. Psychiatry 2007, 12, 206-220. [CrossRef]

169. Ehrenreich, H.; Weissenborn, K.; Prange, H.; Schneider, D.; Weimar, C.; Wartenberg, K.; Schellinger, P.D.; Bohn, M.; Becker, H.; Wegrzyn, M.; et al. Recombinant human erythropoietin in the treatment of acute ischemic stroke. Stroke 2009, 40, e647-e656. [CrossRef]

170. Miskowiak, K.W.; Favaron, E.; Hafizi, S.; Inkster, B.; Goodwin, G.M.; Cowen, P.J.; Harmer, C.J. Effects of erythropoietin on emotional processing biases in patients with major depression: An exploratory fmri study. Psychopharmacology 2009, 207, 133-142. [CrossRef]

171. Velly, L.; Pellegrini, L.; Guillet, B.; Bruder, N.; Pisano, P. Erythropoietin 2nd cerebral protection after acute injuries: A double-edged sword? Pharmacol. Ther. 2010, 128, 445-459. [CrossRef] [PubMed]

172. Rozga, M.; Bittner, T.; Hoglund, K.; Blennow, K. Accuracy of cerebrospinal fluid abeta1-42 measurements: Evaluation of pre-analytical factors using a novel elecsys immunosassay. Clin. Chem. Lab. Med. 2017, 55, 1545-1554. [CrossRef] [PubMed]

173. Zetterberg, H. Applying fluid biomarkers to alzheimer's disease. Am. J. Physiol. Cell Physiol. 2017, 313, C3-C10. [CrossRef] [PubMed]

174. Shaw, L.M.; Vanderstichele, H.; Knapik-Czajka, M.; Clark, C.M.; Aisen, P.S.; Petersen, R.C.; Blennow, K.; Soares, H.; Simon, A.; Lewczuk, P.; et al. Cerebrospinal fluid biomarker signature in alzheimer's disease neuroimaging initiative subjects. Ann. Neurol. 2009, 65, 403-413. [CrossRef]

175. Trombetta, B.A.; Carlyle, B.C.; Koenig, A.M.; Shaw, L.M.; Trojanowski, J.Q.; Wolk, D.A.; Locascio, J.J.; Arnold, S.E. The technical reliability and biotemporal stability of cerebrospinal fluid biomarkers for profiling multiple pathophysiologies in alzheimer's disease. PLoS ONE 2018, 13, e0193707. [CrossRef]

176. Lund, A.; Lundby, C.; Olsen, N.V. High-dose erythropoietin for tissue protection. Eur. J. Clin. Investig. 2014, 44, 1230-1238. [CrossRef]

177. Shi, J.Q.; Shen, W.; Chen, J.; Wang, B.R.; Zhong, L.L.; Zhu, Y.W.; Zhu, H.Q.; Zhang, Q.Q.; Zhang, Y.D.; Xu, J. Anti-tnf-alpha reduces amyloid plaques and tau phosphorylation and induces cd11c-positive dendritic-like cell in the app/ps1 transgenic mouse brains. Brain Res. 2011, 1368, 239-247. [CrossRef]

178. Sun, Y.; Calvert, J.W.; Zhang, J.H. Neonatal hypoxia/ischemia is associated with decreased inflammatory mediators after erythropoietin administration. Stroke 2005, 36, 1672-1678. [CrossRef]

Publisher's Note: MDPI stays neutral with regard to jurisdictional claims in published maps and institutional affiliations.

(C) 2020 by the authors. Licensee MDPI, Basel, Switzerland. This article is an open access article distributed under the terms and conditions of the Creative Commons Attribution (CC BY) license (http://creativecommons.org/licenses/by/4.0/). 